\title{
Stratigraphy and sedimentology of a late Pleistocene incised valley fill: a depositional and paleogeographic model for "Cancagua" deposits in north-western Patagonia, Chile
}

\author{
${ }^{*}$ Rodrigo M. Vega ${ }^{1}$, Mauricio Mella ${ }^{2}$, Sven N. Nielsen ${ }^{1}$, Mario Pino ${ }^{1}$ \\ ${ }^{I}$ Instituto de Ciencias de la Tierra, Edificio Emilio Pugín, Av. Eduardo Morales Miranda, Campus Isla Teja, Universidad Austral de \\ Chile, Valdivia, Chile. \\ rmvega@uach.cl; sven.nielsen@uach.cl;mariopino@uach.cl \\ 2 Servicio Nacional de Geología y Minería, Oficina Técnica Puerto Varas, La Paz 406, Puerto Varas, Chile. \\ mauricio.mella@sernageomin.cl \\ * Corresponding author: rmvega@uach.cl
}

\begin{abstract}
Late Pleistocene sedimentary deposits outcropping around Valdivia city, locally known as Cancagua, have been subject of contrasting interpretations, from glacial to interglacial sediments. Opposing views emerge from focusing on upstream or coastal sedimentary controls, within a zone were these potentially overlap through a full glacial cycle. Here we present the first detailed facies analysis and a broad chronological framework, reconciling previous interpretations in a single paleogeographic model that encompasses the last glacial cycle. Seven facies associations are described, interpreted as an estuarine complex developed primarily during the last glacial cycle's highstand, yet accumulating sediments during a substantial part of the falling stage. These results offer the opportunity to extend paleoenvironmental records through a full glacial cycle in northern Patagonia.
\end{abstract}

Keywords: Late Pleistocene, Cancagua, Volcaniclastic, Facies analysis, Glacial-interglacial cycles, Northpatagonia.

RESUMEN. Estratigrafía y sedimentología del relleno de un valle inciso del Pleistoceno tardío: un modelo deposicional y paleogeográfico para los depósitos de "Cancagua" en la Patagonia noroeste, Chile. Los depósitos sedimentarios del Pleistoceno tardío que afloran en torno a la ciudad de Valdivia, localmente denominados Cancagua, han sido objeto de interpretaciones contrastantes, desde depósitos glaciales hasta interglaciales. Estas visiones opuestas surgen del énfasis en los factores que controlan la sedimentación río arriba o en torno a la desembocadura, en una zona en donde estos posiblemente se traslapan durante un ciclo glacial completo. Este trabajo presenta el primer análisis de facies detallado, junto a un marco cronológico preliminar, reconciliando las interpretaciones anteriores en un solo modelo paleogeográfico que abarca el último ciclo glacial completo. Se describen siete asociaciones de facies, interpretadas como un complejo estuarino desarrollado principalmente durante la posición alta del nivel relativo del mar, no obstante acumulando sedimentos durante una porción sustancial del proceso de caída del nivel base. Estos resultados proveen la posibilidad de extender los registros paleoambientales norpatagónicos a través de un ciclo glacial completo. 


\section{Introduction}

Understanding past climate changes and landscape response are essential for assessing the impact and outcomes of industrial society on the environment, and therefore on itself. The former Patagonian Ice Sheet (PIS) has received considerable attention for it inherited a detailed land record of past glacier fluctuations (Mercer, 1976; Porter, 1981; Denton et al., 1999; McCulloch et al., 2000; Glasser et al., 2008; García, 2012; among others). Data has proven indispensable for testing climate models, discussing connections and possible driving mechanisms governing climate change (e.g., Denton et al., 2010), as well as obtaining detailed records of climate variability suitable for comparison with modern data (e.g., De Batist et al., 2008; Heirman et al., 2011).

Most of this effort has focused on the last glacial maximum (LGM) and Holocene (e.g., García et al., 2012; Moreno et al., 2014; Strelin et al., 2014), in part because of the abrupt character of this transition, but also because detailed records, such as those preserved in peat bogs and lake sediments, began to accumulate after glacier withdrawal. Fluvial sediments, along with advances in dating techniques, offer the opportunity to extend these records back in time (Wallinga, 2002) as a complementary approach, allowing a detailed reconstruction of (localized) landscape organization and changes, together with a source-to-sink perspective on landscape dynamics and response to climate oscillations (e.g., Carter et al., 2010; Goodbred Jr., 2003).

This paper focuses on late Pleistocene coastal sedimentary deposits outcropping around Valdivia city ( $\left.39^{\circ} 50^{\prime \prime} \mathrm{S}\right)$, connected to the fluvial system that drained the northernmost piedmont glacier lobes of the PIS, as a first step toward reconstructing landscape response to glacial-interglacial cycles in South America.

\subsection{Previous work and contrasting views}

Valdivia city (Fig. 1) is surrounded by prominent terraces widely extended throughout the Valdivia river course and connected to a coastal cliff along the shoreline. Upstream they merge with the plains that have been inferred to belong to the Santa María drift (Mercer, 1976; Porter, 1981, possibly MIS 6). Around Valdivia city, most outcrops exhibit a volcaniclastic sandstone locally known as "Cancagua".
Several authors have assigned an interglacial (MIS 5e) age to "Cancagua" deposits (Astorga and Pino, 2011; Illies, 1970; Latorre et al., 2007, among others) based on sea level reconstructions, by relating valley aggradation to interglacial sea level highstand and river incision to glacial sea level lowstand. The proposed age is concordant with two minimum ages of $>50 \mathrm{ka}$ BP obtained by radiocarbon dating (Astorga and Pino, 2011; Latorre et al., 2007) and with field descriptions, where part of the volcaniclastic component has been observed overlying glaciofluvial gravels assigned to the Santa María glaciation and underlying similar deposits interpreted as the Llanquihue drift (MIS 4-2; Arenas et al., 2005). More recently Mella et al. (2012) described interlocking relations between these deposits and those assigned to the Santa María drift, relating them to the transition between the middle and late Pleistocene.

Illies (1970) first noted the volcaniclastic component and related it to the possibility of enhanced volcanic activity during the last interglacial. Later, Latorre et al. (2007), based on composition and sediment source, described these deposits as composed of two distinct facies, an autochthonous one comprising sediment derived from the local metamorphic basement and an allochthonous facies composed mainly by volcaniclastic material, the latter being directly linked to volcanism through laharic flows reaching the coast. While this hypothesis is in agreement with some observations such as the green hornblende content, tightly related to pyroclastic input (Smith and Lotosky, 1995), laharic facies have not been clearly differentiated from posteruptive or intereruptive facies.

A completely opposed interpretation arises from Laugenie's (1982) seminal work on glacial geomorphology in the Andean piedmont. As interpretation follows from the glacially controlled sandar terraces upstream toward the coast, these same deposits are assigned to the Santa María drift, incised prior to the emplacement of the Llanquihue drift. These contradictory views emerge from focusing either on costal forcing factors or on upstream forcing factors and extrapolating the response to the whole river course, as discussed by Blum and Tornqvist (2000).

Here we revise this interpretations in the light of detailed facies analysis and present a broad chronostratigraphical framework, reconciling previous views in a single paleogeographical model. 

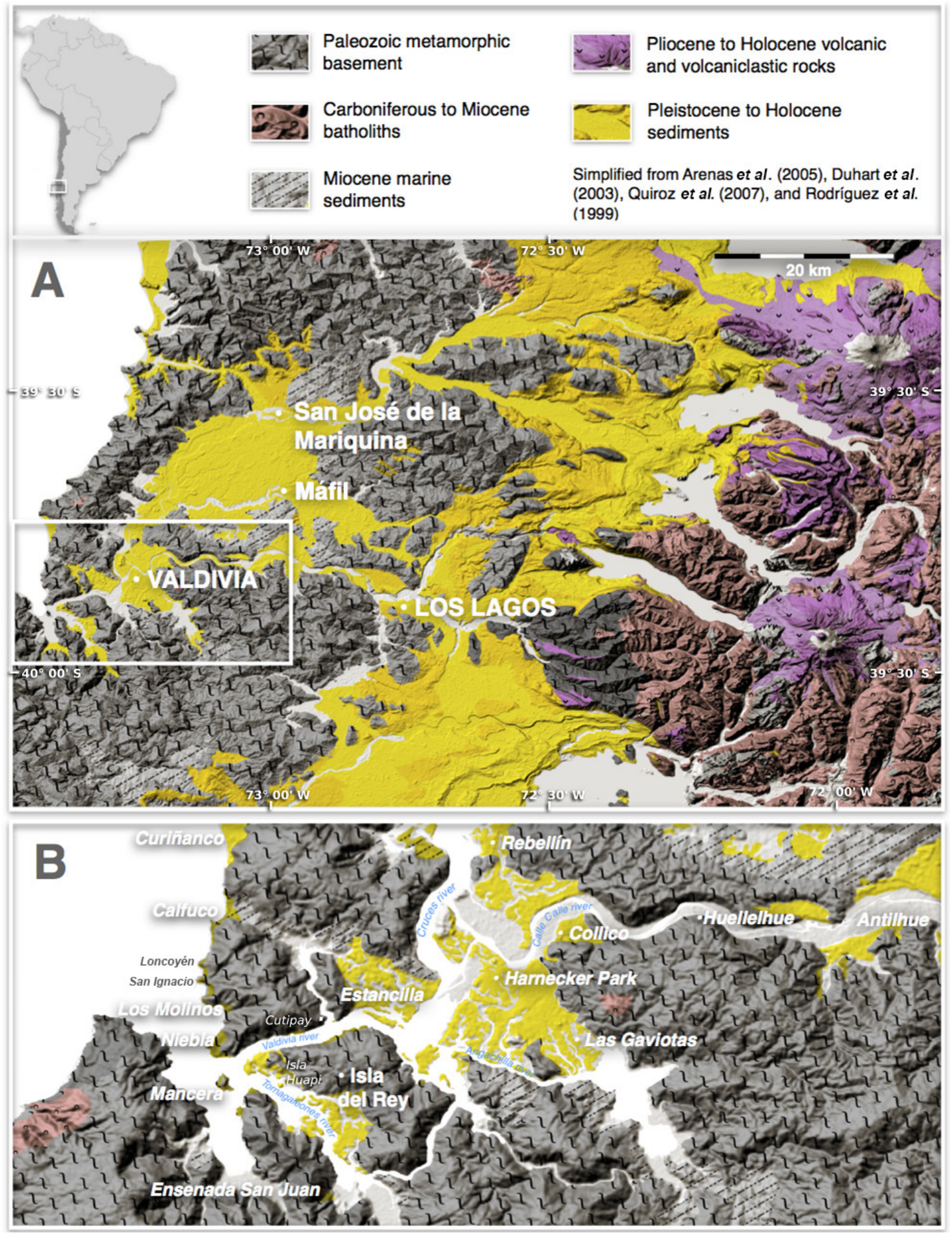

FIG. 1. Regional setting. A. Simplified geologic map. Note the contrasting lithology between the Andean and Coastal Cordillera. Rectangular area around Valdivia city depicts zone enlarged in B; B. Detail of the study area and locality names referred to in the text. 


\section{Regional setting}

Valdivia city is located in the Coastal Cordillera in south central Chile, an active convergent margin where the oceanic Nazca plate subducts beneath the South American continental plate. In a broad sense, the region consists of three main morphostructural units differentiated from $\mathrm{W}$ to $\mathrm{E}$ : the Coastal Cordillera, the Central Depression and the Andean Cordillera. The Coastal Cordillera is composed of metamorphic rocks from a Paleozoic accretionary wedge and locally of plutonic rocks representing a Permo-Carboniferous magmatic arc (Glodny et al., 2006, and references therein). A few intrusions of Cretaceous granitoids are localized within this complex. The main Cordillera, consisting mostly of plutonic rocks, is partially covered by Pliocene-Quaternary volcanic rocks of basaltic-andesitic composition (Glodny et al., 2006). The Central Depression is filled with Pliocene to Holocene glaciofluvial and volcaniclastic deposits derived from the Andean Cordillera (Glodny et $a l ., 2006$, and references therein). The Central Depression is interrupted in the Valdivia region by the Loncoche Massif, a prolongation of the Coastal Cordillera into the main Andean Cordillera, and thus Pliocene-Quaternary sediments are confined to intermontane valleys (Illies, 1970; Laugenie, 1982; Fig. 1).

In a North-South sense, the forearc in southcentral Chile is morphotectonically differentiated in three fault bounded segments (Rehak et al., 2008). As opposed to the northern and southern segments that record pronounced Quaternary uplift, the central Toltén segment, in which Valdivia city is included, exhibits a steady behavior, with uplift restricted to the coastal region (Rehak et al., 2008).

\section{Study area and methods}

\subsection{Mapping}

Mapping was based on interpretation of 1:50.000 aerial photographs under stereoscope, ETM+ imagery and SRTM derived DEMs, and previous maps by Arenas et al. (2005), Duhart et al. (2003), Laugenie (1982), Mella et al. (2012), Quiroz et al. (2007) and Rodríguez et al. (1999). The zone was extensively mapped by water and land, describing and sampling all available outcrops. Sorting and roundness estimations were performed by visual comparison with charts included in Stow (2010). Grain size was estimated by visual comparison with resin embedded sieved sand into five categories, from very fine to very coarse, with breakpoints at $0 \phi, 1 \phi, 2 \phi$ and $3 \phi$. Lithofacies were coded following Miall (1985) and extending codes as necessary for coastal facies. Facies were grouped in seven facies associations under sedimentologic and genetic criteria to ease correlation. Digital maps were produced using QGIS 2.0.1-Dufour.

\subsection{Dating}

Samples for optically stimulated luminescence (OSL) dating were retrieved in $20 \mathrm{~cm}$ long hydraulic PVC tubes aided by a specially designed case acting as a coring device. Tubes were sealed with PVC caps for shipping. A second sample from the surrounding $20 \mathrm{~cm}$ radius was used for estimating dose rate. OSL analyses were preformed in the Luminescence Dating Research Laboratory, Department of Earth and Environmental Sciences, University of Illinois-Chicago. Equivalent dose was determined by the multiple aliquot regenerative dose method under blue $(470 \mathrm{~nm})$ excitation (Jain et al., 2003). U, Th and $\mathrm{K}$ were determined by ICP-MS at Activation Laboratory Ltd., Ontario. Average water content was estimated from particle size characteristics assuming periodic wetting in the vadose zone. Cosmic dose rate component was taken from Prescott and Hutton (1994) based on latitude, longitude, elevation, and burial depth of samples. Radiocarbon dating was made at the NSFArizona AMS Laboratory and the UCIAMS-W.M. Keck Carbon Cycle Accelerator Mass Spectrometry Laboratory, University of California at Irvine. ${ }^{14} \mathrm{C}$ dates were calibrated based on the IntCal13 calibration curve (Reimer et al., 2013).

\section{Facies associations}

Lithofacies were grouped in seven facies associations (FA) reflecting distinct depositional environments. Facies were gathered according to lateral and vertical relations following Walther's law, and to a common suite of inferred sedimentary processes governing deposition. Individual facies are described in the following section as part of each FA. A summary is given in table 1 . 
TABLE 1. SUMMARY OF PRINCIPAL CHARACTERISTICS OF FACIES ASSOCIATIONS AND INTERPRETATION.

\begin{tabular}{|c|c|c|c|c|c|}
\hline & Facies & $\begin{array}{l}\text { Grain size and } \\
\quad \text { sorting }\end{array}$ & Grain attributes & Fossil content & Interpretation \\
\hline $\begin{array}{l}\text { FA 1: Shallow } \\
\text { marine }\end{array}$ & $\begin{array}{l}\text { Sh, Sl, } \\
\text { Ssw, St, P, } \\
\text { Sht }\end{array}$ & $\begin{array}{l}\text { Medium to very } \\
\text { coarse well sorted } \\
\text { sand }\end{array}$ & Well rounded & $\begin{array}{l}\text { Shell fragments } \\
\text { within St, rootlets } \\
\text { within P }\end{array}$ & $\begin{array}{l}\text { Shallow marine } \\
\text { shoreface to foreshore } \\
\text { deposits }\end{array}$ \\
\hline $\begin{array}{l}\text { FA 2: Coastal } \\
\text { bar }\end{array}$ & $\begin{array}{l}\text { St, Sp, Sh, } \\
\text { Sl, P }\end{array}$ & $\begin{array}{l}\text { Fine to very } \\
\text { coarse, well sorted } \\
\text { sand }\end{array}$ & $\begin{array}{l}\text { Subrounded to } \\
\text { well rounded }\end{array}$ & $\begin{array}{l}\text { Rootlets within } \mathrm{P} \text {, } \\
\text { extending downwards } \\
\text { into Sp sets }\end{array}$ & $\begin{array}{l}\text { Coastal bar association, } \\
\text { including shallow } \\
\text { marine, coastal dune and } \\
\text { fluvial sand bars }\end{array}$ \\
\hline $\begin{array}{l}\text { FA 3: Estuary } \\
\text { mouth } \\
\text { complex }\end{array}$ & $\begin{array}{l}\text { St, Sp, Sr, } \\
\text { Sht, Ssh, } \\
\text { Sm, Sfl, } \\
\text { Fl, C, P, } \\
\text { Sh }\end{array}$ & $\begin{array}{l}\text { Fine to medium } \\
\text { well sorted sand }\end{array}$ & Well rounded & $\begin{array}{l}\text { Shell fragments } \\
\text { within St/Sp, } \\
\text { meter scale } \\
\text { mollusc shellbeds, } \\
\text { Ophiomorpha traces, } \\
\text { cirripeds, rootlets, } \\
\text { plant debris, wood } \\
\text { fragments }\end{array}$ & $\begin{array}{l}\text { Coastal barrier and } \\
\text { estuary mouth sand } \\
\text { complex, including } \\
\text { back barrier swamps, } \\
\text { marshes and tidal flats, } \\
\text { washover fans, tidal } \\
\text { inlets, tidal bars and bay } \\
\text { facies. Grades laterally } \\
\text { and upwards to shallow } \\
\text { marine and coastal bar } \\
\text { FAs }\end{array}$ \\
\hline $\begin{array}{l}\text { FA 4: Central } \\
\text { estuary }\end{array}$ & $\begin{array}{l}\text { Sht, Sr, } \\
\text { Sfl, Fm, St }\end{array}$ & $\begin{array}{l}\text { Very fine to } \\
\text { medium, moderate } \\
\text { to well sorted sand } \\
\text { and mud }\end{array}$ & $\begin{array}{l}\text { Subangular to } \\
\text { subrounded }\end{array}$ & $\begin{array}{l}\text { Bivalves (Veneridae, } \\
\text { Tagelus sp), Bivalve } \\
\text { traces shell fragments, } \\
\text { small arthropod } \\
\text { burrows in Sht }\end{array}$ & $\begin{array}{l}\text { Central estuary basin, } \\
\text { grading laterally to tidal } \\
\text { channels and tidal flats } \\
\text { towards the valley edges }\end{array}$ \\
\hline $\begin{array}{l}\text { FA 5: } \\
\text { Estuarine } \\
\text { bayhead delta }\end{array}$ & $\begin{array}{l}\text { Sh, Sr, St, } \\
\text { Fl, P, Sht }\end{array}$ & $\begin{array}{l}\text { Very fine } \\
\text { to medium, } \\
\text { moderately sorted } \\
\text { sand. Occasional } \\
\text { gravel and mud }\end{array}$ & $\begin{array}{l}\text { Subangular to } \\
\text { subrounded sand, } \\
\text { well rounded } \\
\text { gravel clasts }\end{array}$ & $\begin{array}{l}\text { Rootlets, leaves and } \\
\text { small vegetal remains, } \\
\text { occasionally small } \\
\text { wood fragments }\end{array}$ & $\begin{array}{l}\text { Bayhead delta, including } \\
\text { channel, levees, swamps } \\
\text { and overbank facies }\end{array}$ \\
\hline FA 6: Fluvial & $\begin{array}{l}\text { Gt, Gp, St, } \\
\text { Sp, Fl }\end{array}$ & $\begin{array}{l}\text { Coarse sand and } \\
\text { gravel, moderately } \\
\text { to well sorted. } \\
\text { Fines less common }\end{array}$ & $\begin{array}{l}\text { Subangular to } \\
\text { subrounded sand, } \\
\text { well rounded } \\
\text { gravel }\end{array}$ & $\begin{array}{l}\text { Rootlets, leaves and } \\
\text { other vegetal remains }\end{array}$ & $\begin{array}{l}\text { Fluvial channel and } \\
\text { floodplain facies, } \\
\text { including swamps and } \\
\text { splays }\end{array}$ \\
\hline $\begin{array}{l}\text { FA 7: Slope } \\
\text { deposits }\end{array}$ & $\begin{array}{l}\text { Gms, Gm, } \\
\text { Gt, Sp, Sh, } \\
\text { C, P }\end{array}$ & $\begin{array}{l}\text { Clay to boulder } \\
\text { sized gravel, } \\
\text { moderately sorted } \\
\text { to diamictic }\end{array}$ & $\begin{array}{l}\text { Angular to } \\
\text { subrounded }\end{array}$ & Wood, rootlets & $\begin{array}{l}\text { Slope and alluvial fan } \\
\text { deposits, including debris } \\
\text { flows and gravitational } \\
\text { processes in general, } \\
\text { small streams, peat bogs } \\
\text { and soils }\end{array}$ \\
\hline
\end{tabular}

Facies codes are those of Miall (1985), expanded by including the following: Ssw: swaley cross bedded sand; Sht: stratified or laminated, intercalated sand and mud; Ssh: shellbeds.

\subsection{Facies association 1 (FA 1): Shallow marine}

\subsubsection{Description}

FA 1 is mainly composed of medium to very coarse, well sorted, very well rounded clast supported sandstones. Among outcrops, four distinct lithofacies can be identified. The better exposed depicts sub- horizontal parallel stratification together with low angle cross-bedding (Sh/Sl; Fig. 2A). Occasional granule beds about $3 \mathrm{~cm}$ thick occur within these facies. Granules are perfectly rounded, forming part of a bimodal grain size distribution in concert with coarse sand (Fig. 2A). Subhorizontal laminae dip gently in a basinward direction and are frequently 

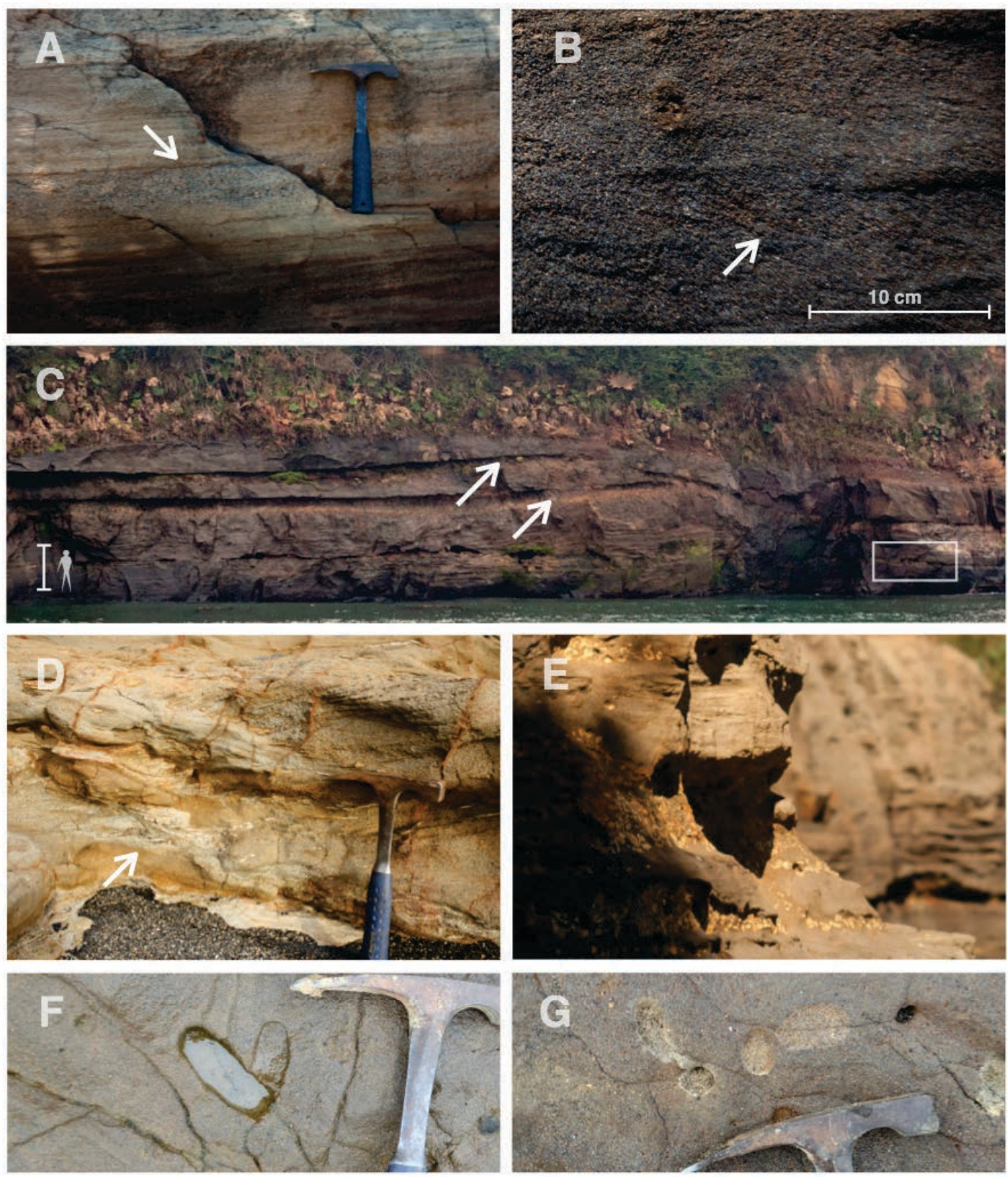

FIG. 2. Selected sedimentary facies and attributes belonging to facies association FA 1. A. Sh/S1 facies showing basinward gentle dip and granule bed (arrow); B. Small scale filled erosion surface within $\mathrm{Sh} / \mathrm{Sl}$ facies interpreted as an upstream migrating antidune track (arrow); C. General view of FA 1 facies, scale bar is approximately $2 \mathrm{~m}$ high. Arrows point at two paleosoils merging eastwards (right). White box shows area enlarged in panel E; D. St facies, note calcareous clast accumulations (arrow); E. A pumice layer; F-G. Trypanites isp over FA 1 in Playa Grande (Niebla).

truncated by flat erosion surfaces at low angles. Small scale irregular erosion surfaces filled with laminated or structureless sand can be seen (Fig. 2B). Localized, pebble sized pumice layers occur in some exposures, supported by a sand matrix (Fig. 2E). Two discrete paleosoil levels $(\mathrm{P})$ are interbedded within $\mathrm{Sh} / \mathrm{Sl}$ sand bodies (Fig. 2C). Southward, this facies grades to a coarse, swalley cross-bedded sandstone 
(Ssw). A third facies retains main clast attributes while exhibiting distinct trough cross-bedded units (St). Troughs contain abundant marine invertebrate fragments concentrated as small aprons at the bottom of each lamina (Fig. 2D). toward the upper portion of this facies some mud drapes appear, together with mudball concentrations as it grades to a fourth, faintly heterolithic facies (Sht), in which sand and mud alternate in a thinly laminated pattern. Within the rather poor exposure it is possible to observe soft-sediment deformation structures, concentrated below a massive, concave upward based sand body.

\subsubsection{Occurrence}

FA 1 outcrops exclusively in Niebla (Fig. 1B), where it forms two distinct units. The older is exposed in Playa Grande as the basal layer. Overlying facies rest upon a sharp, locally erosive contact. The contact surface shows abundant borings attributed to Trypanites isp. (Fig. 2F). Borings have sharp edges with no lining, they are subhorizontal, $\sim 2 \mathrm{~cm}$ wide shafts with rounded ends. Some borings show a consolidated sand sized infill (Fig. 2G). The second, younger unit outcrops in Playa Chica, alternating with paleosoils as it grades to FA 3.

\subsubsection{Interpretation}

FA 1 is interpreted as shallow marine deposits, ranging from foreshore to lower shoreface facies. $\mathrm{Sh} / \mathrm{Sl}$ facies forms under supercritical flow conditions, characteristic of the upper shoreface-foreshore environment. Ssw facies derive from the occurrence of both oscillatory and directional currents, and are here inferred to represent storm-weather deposits within the shoreface. The northwestern end of exposure exhibits some discrete pumice layers and two paleosoils interlocked with $\mathrm{Sh} / \mathrm{Sl}$ (Fig. 2C). This section is inferred to belong to the foreshore or even backshore portion of the shallow marine environment, alternating with a vegetated berm under relative sea level oscillations. Together, these three sections form a coherent, NW-SE oriented transition from backshore/foreshore to shoreface subenvironments within a $200 \mathrm{~m}$ horizontal distance. St and Sht facies are present only in Playa Grande, within the older unit. We interpret these facies as the transition from upper to lower shoreface conditions, relating $\mathrm{St}$ facies to longshore or rip currents (Zecchin, 2007) and Sht to the transitional zone between shoreface and offshore environments.

\subsection{Facies association 2 (FA 2): Coastal bar}

\subsubsection{Description}

Throughout available outcrops, this facies association exposes three principal lithofacies. The first one consists of a well sorted, clast supported, sub-rounded to rounded, medium to very coarse trough cross bedded sand (St). Troughs are one to two meters wide, arranged in sets nearly half a meter thick, bounded by subhorizontal sharp surfaces (Fig. 3A). Occasionally, some fine platy gravel clasts $(<5 \mathrm{~mm})$ can be seen. The second facies exhibits sub rounded, well sorted, clast supported, medium to fine parallel laminated/low angle cross-bedded sand ( $\mathrm{Sh} / \mathrm{Sl}$ ). Individual laminae show inverse grading and a very loose packaging (Fig. 3B). Shallow and wide sub-parallel scours are ubiquitous and occasionally filled with planar cross-laminated sand. A pumice layer occurs within this facies, pumice clasts are pebble sized, supported by a sandy matrix and forming a discrete $10 \mathrm{~cm}$ layer (Fig. 3C). The third facies is composed of well rounded, well sorted, clast supported, fine to medium planar cross-bedded sand (Sp). Individual laminae show well developed inverse grading. Sand bodies are arranged in sets, each one of these consisting of inclined parallel strata dipping at an angle of $30^{\circ} \pm 2.5$. Paleodirections vary between sites yet show a discrete within-site dispersion and a general eastward trend (Fig. 4). Sets are bounded by third order, sub-horizontal or inclined surfaces. Within these surfaces, laterally extensive and well developed paleosoils (P) are common. Individual set thickness ranges between five and ten meters (Fig. 3D-E). Second order surfaces are sharp and straight contacts, truncating first order stratification at such a similar angle that they are hardly noticed.

\subsubsection{Occurrence}

FA 2 is widespread throughout the coast, from Niebla to Curiñanco (see Fig. 1B for location names). The best exposure is in Calfuco, where the complete suite of facies can be seen within a few outcrops. The spatial distribution of these facies is closely related to local geomorphological character. Both $\mathrm{Sh} / \mathrm{Sl}$ and $\mathrm{St}$ facies occur in association with flat surfaces rising about 20 meters above sea level ( $\mathrm{m}$ a.s.1), while Sp facies are invariably related to an undulating topography ranging between near 20 to almost $60 \mathrm{~m}$ a.s.1. 

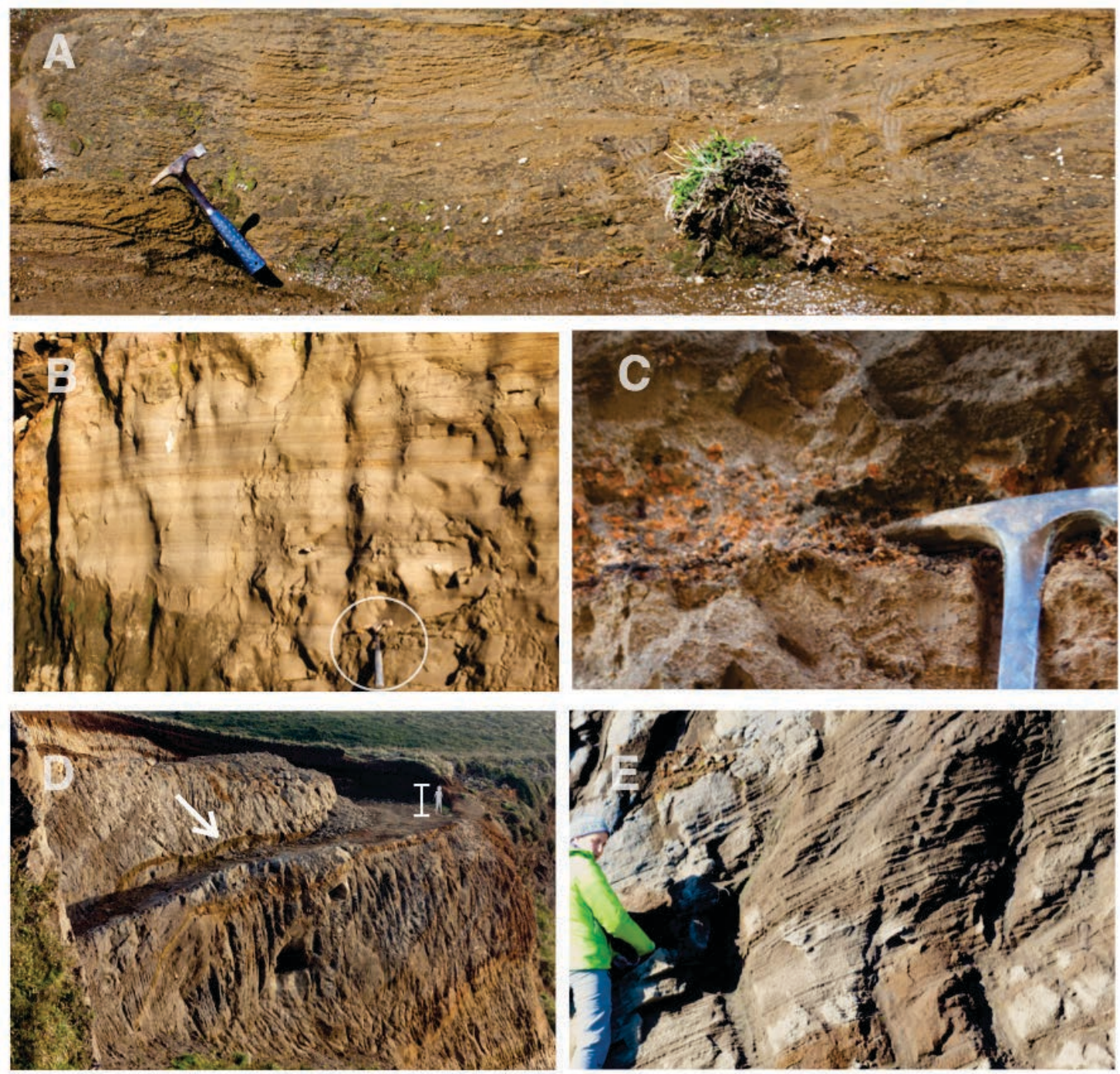

FIG. 3. Sedimentary facies pertaining to facies association FA 2. A. St facies; B. Sh/Sl facies, note hammer at the bottom (white circle) for scale; C. Pumice layer within Sh/Sl facies; D. Composite panorama showing Sp facies in Loncoyén. Arrow points to paleosoil bounding inclined strata set (see text for details). Scale bar approximately $2 \mathrm{~m}$ high; E. Detail of inclined stratification in Sp facies.

\subsubsection{Interpretation}

FA 2 is interpreted as a costal bar association where the continentward facies have been better preserved than their basinward counterparts. St facies represents fluvial dominated channel 3D sand dunes. This is consistent with sedimentary structure, indicating deposition as bedload traction sediments from unidirectional currents under subcritical flow conditions. Fabric and sorting support this view.
$\mathrm{Sh} / \mathrm{Sl}$ facies respond to a wider set of processes. Parallel lamination and low angle cross-bedding are formed under upper flow regime conditions. Based on this and on the ubiquitous shallow and wide erosion surfaces we infer these deposits to have accumulated in a foreshore environment. Occasional planar cross-laminated infills are the product of small scale migrating asymmetrical ripples, formed within shallow creeks or tidal 


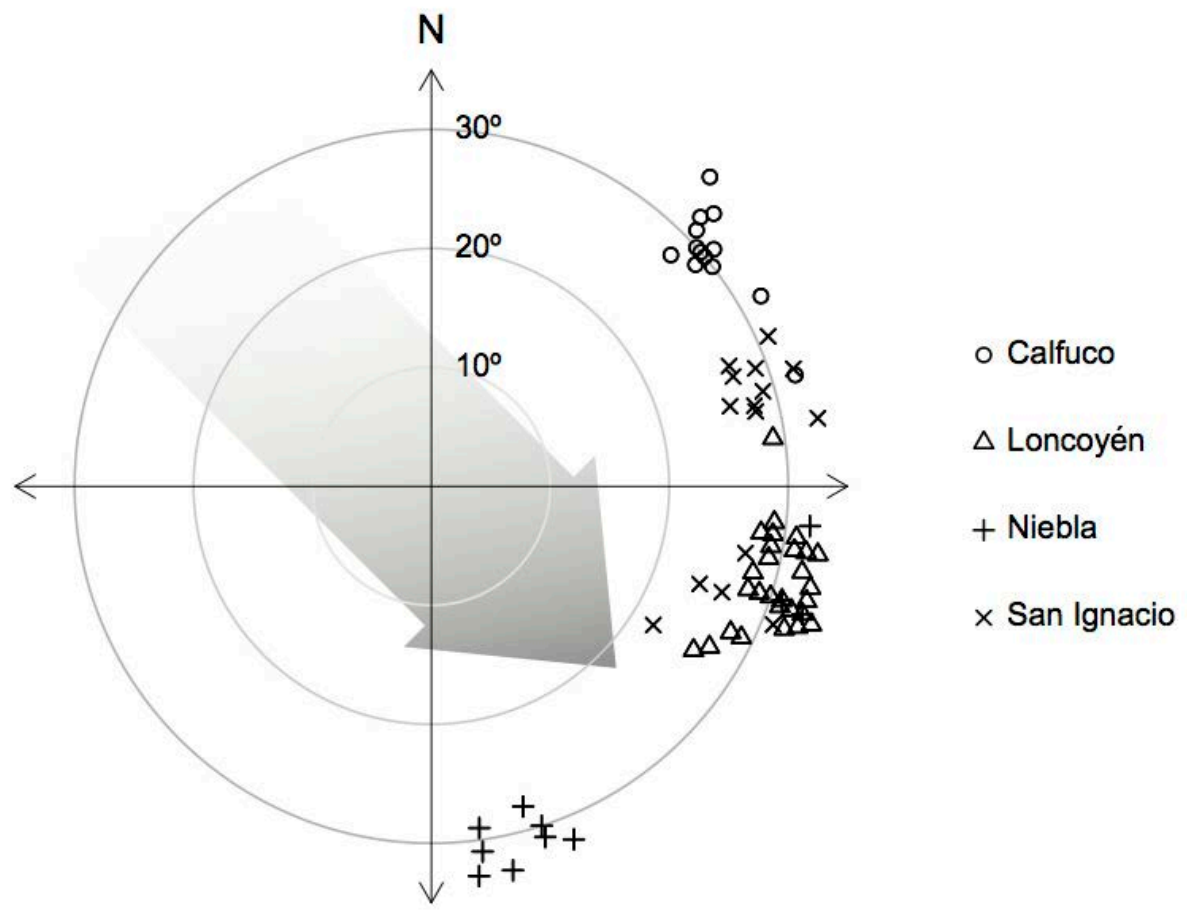

FIG. 4. Palaeodirections from Sp facies within facies association FA 2, inferred to be dune deposits. Points represent direction of the horizontal vector normal to the dip plane, distance from the origin reflects dipping angle.

channels. Inversely graded, loose fabric laminae represent wind ripple drift deposits. As is fairly common to observe today, pumice clasts are readily transported by rivers to the sea after volcanic eruptions, being thoroughly spread by longshore currents and ending up in the foreshore-backshore zone. The pumice layer within $\mathrm{Sh} / \mathrm{Sl}$ facies thus supports our interpretation. Both St and $\mathrm{Sh} / \mathrm{Sl}$ facies are genetically related, the former grading to the latter in a basinward direction as the river course reaches the shoreline, thus accounting for the geomorphological link between them. Sp facies represents coastal transverse dune deposits. The excellent sorting and fine grain size are in good agreement with eolian transport processes. Moreover, paleodirections neatly conform to the dominant NW wind direction (Fig.4), and dip angles of primary stratification are fairly close to the $33^{\circ}$ angle of repose for dry sand (Kocurek, 1996). Within laminae inverse grading supports avalanching as a settling process, further confirming the eolian interpretation as this is the primary mechanism of dune migration (Kocurek, 1996).

\subsection{Facies association 3 (FA 3): Estuary mouth complex}

\subsubsection{Description}

This FA is formed by clast supported, well rounded, well sorted, medium to fine sands punctuated by fine deposits. The innermost (continentward) sections consist of planar or through cross-bedded units (Sp/St), arranged in $\sim 0.3-0.5 \mathrm{~m}$ thick sets, bounded by erosive, nearly plane or concave-up surfaces. Ripple cross-laminated sand ( $\mathrm{Sr}$ ) occasionally fills the basal portion. Paleodirections point toward both continent and basinward sediment transport, although opposite directions occur in different sections. Shell fragments are ubiquitous within cross-bedded units, along with well developed Ophiomorpha traces (Fig. 5). Crudely bedded, concave up, several meters thick shellbeds ( $\mathrm{Ssh}$ ) occur within this FA, with remarkable exposures in the western tip of Isla del Rey and around Ensenada San Juan (Fig. 1B).

Analysis from an exceptionally well preserved deposit in Isla Huapi revealed the presence of the gastropods Crepipatella cf. dilatata, Crucibulum 

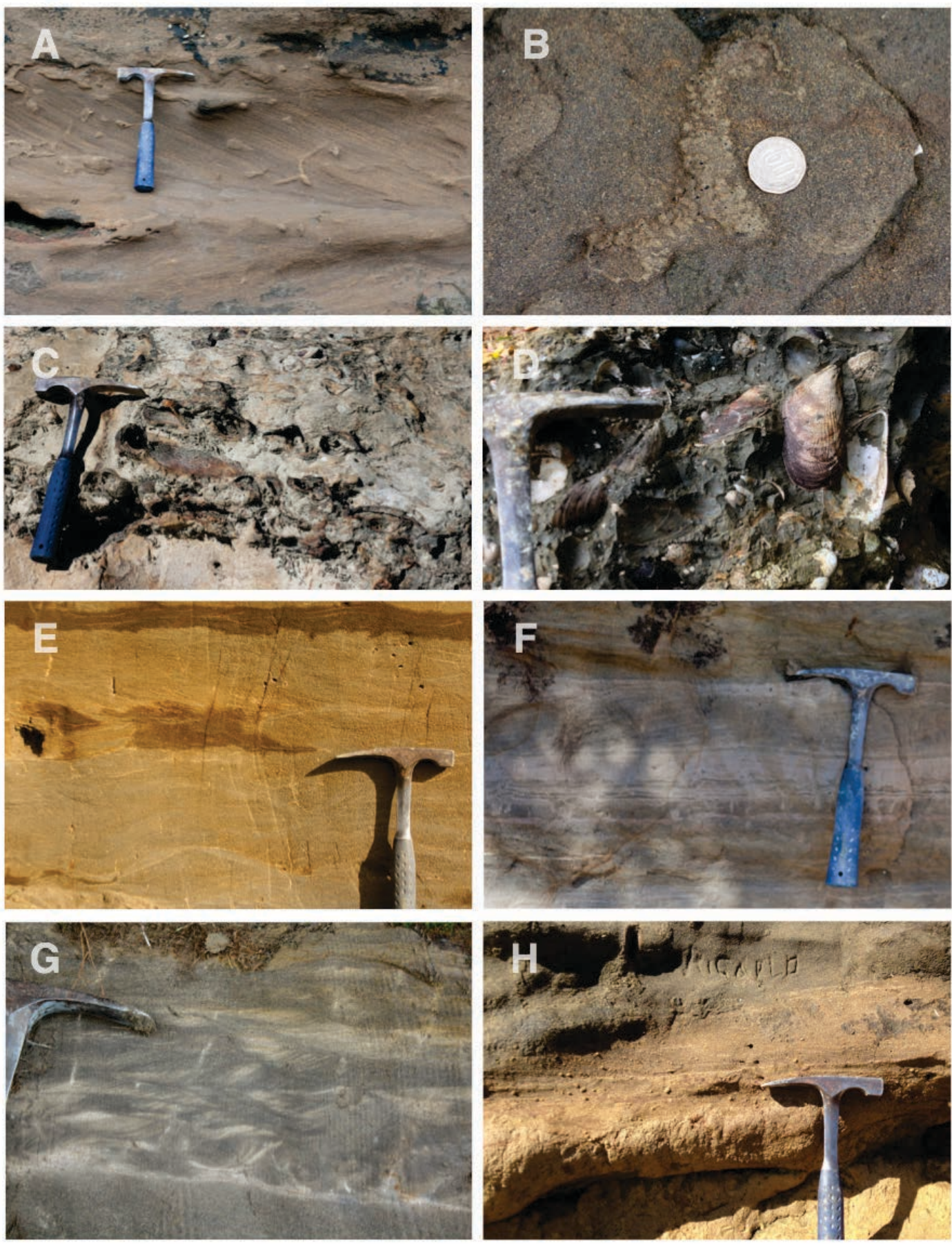

FIG. 5. Selected sedimentary facies and attributes belonging to facies association FA 3. A. Sp/St facies with relatively abundant Ophiomorpha/Thalassinoides isp burrows, Isla del Rey; B. Detail of Ophiomorpha isp pellet lined burrow; C. Shellbeds (Ssh) in Isla del Rey preserved as iron coated molds; D. Rare carbonate preservation in Ssh facies in Isla Huapi. Note closely spaced Aulacomya sp valves in right portion; E. Sh/Sr facies in Playa Grande, ripple bedding showing bidirectional trends; F. Sht facies with prominent mud drapes, Isla de Mancera; G. Complex 3D ripple lamination, Isla de Mancera; H. Paleosoil (P) within sand bodies in Playa Grande (Niebla). Hammer head marks the contact surface between paleosoil and overlying sand, note erosive character of contact, including rip up, iron indurated soil clasts within basal portion of sandstone. 
quiriquinae, Nassarius gayi, and Columbella cf. rubra along with the bivalves Choromytilus chorus, Aulacomya atra, Tagelus dombeii, Ameghinomya antiqua, and Cumingia mutica (Fig. 6), indicating a water depth of less than $20 \mathrm{~m}$. Here bivalves preserve both valves still attached to one another or lying closely together. Carbonate preservation within these deposits is extremely rare, nevertheless molds resembling these same species are widely distributed within this FA (Fig. 5).

Toward the coast a distinctive pattern of alternating sand and fines bodies develops, especially conspicuous in Playa Grande (Niebla) and Isla de
Mancera. Here sand bodies are usually one meter thick and tens of meters wide, exhibiting parallel or subparallel stratification along with ripple cross bedding $(\mathrm{Sh} / \mathrm{Sr})$. Fossil preservation within sand layers is rather poor, yet clay filled molds resembling plant remains and barnacles have been observed. Flasers and mud drapes locally gain abundance conforming a fairly heterolithic facies (Sfl/Sht; Fig. 5). Eventually, these sand bodies grade laterally to massive or trough cross bedded ( $\mathrm{Sm} / \mathrm{St})$, finning upward units resting upon concave-up surfaces. Fines within this FA consist of crudely laminated silt or massive silty clay, filling concave

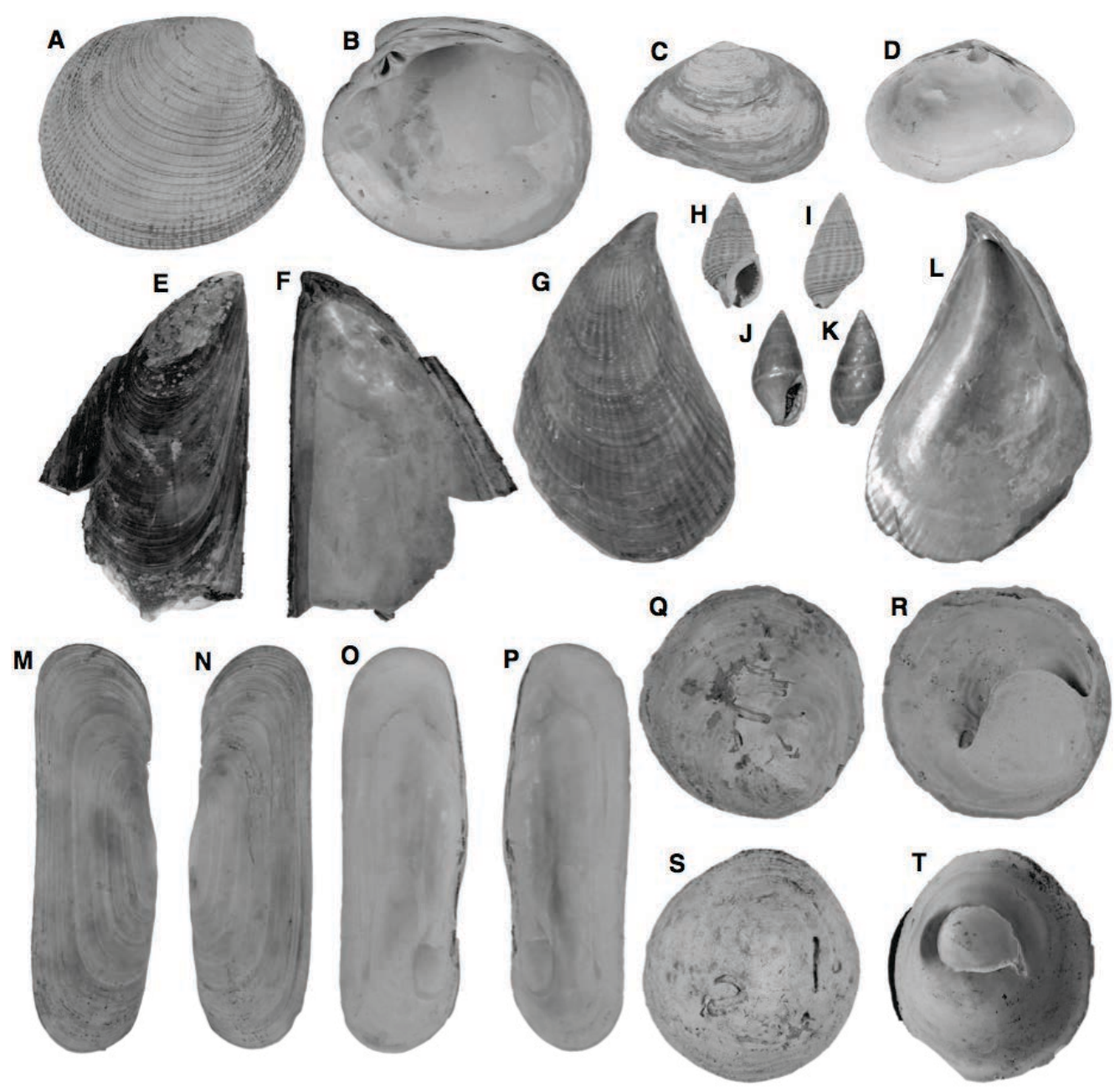

FIG. 6. Pleistocene Mollusca from Huapi Island. A-B. Ameghinomya antiqua, length $47.3 \mathrm{~mm}$; C-D. Cumingia mutica, length $30.6 \mathrm{~mm}$; E-F. Choromytilus chorus, height of fragment $90.8 \mathrm{~mm}$; G, L. Aulacomya atra, height $75 \mathrm{~mm}$; H-I. Nassarius gayi, height $12.8 \mathrm{~mm}$; J-K. Columbella cf. rubra, height $7.8 \mathrm{~mm}$; M-P. Tagelus dombeii, length $88 \mathrm{~mm}$; Q-R. Crepipatella cf. dilatata, diameter $44 \mathrm{~mm}$; S-T. Crucibulum quiriquinae, diameter $31 \mathrm{~mm}$. 
up surfaces ( $\mathrm{Fl})$. The basal portion usually contains abundant, decimeter long wood fragments, while fossil leaves are dominant upward. Some of these silt bodies show rootlets and increasing organic content toward the top, grading to well developed, wood bearing peat layers $(\mathrm{C})$.

These facies grade laterally to decimeter thick clayey paleosoils (F). Where this alternating pattern fades, several meters thick sand successions formed by parallel or trough cross bedded, one to two meters thick packages occur. Individual laminae show predominantly normal grading, although inversely graded, sometimes inclined laminae are not rare. Each package is bounded by a flat reactivation surface characterized by fine sediment and plant remains accumulation. Rootlets are common and weathering degree suggests incipient pedogenesis.

Soft sediment deformation structures are ubiquitous within FA 3, particularly, yet not restricted to contacts in which sand overlies peat layers. Here flame structures and fully developed load casts occur. Where sand successions lie on top of clay strata incipient diapirism can be observed, deformation protruding upward into sand facies (Fig. 5). Additionally, two growth faults have been recorded in Playa Grande, where sand accumulation is thickest (Fig. 5).

\subsubsection{Occurrence}

Facies association 3 is distributed along the coast, exclusively around the Valdivia river outlet. Innermost sections conformed by $\mathrm{Sp} / \mathrm{St}$ facies occur at both sides of Isla del Rey, through the Valdivia and Tornagaleones rivers (Fig. 1B). Shellbeds are concentrated toward the south, from the western tip of Isla del Rey to Ensenada San Juan. All of these facies are related to terrace flights following the river courses. Alternating sand and fines are prominent in Isla de Mancera and Playa Grande, where it grades laterally to the younger unit pertaining to FA 1 , and unconformably overlies the older one. In Playa Grande there is a marked north-south trend whereby $\mathrm{Sh} / \mathrm{Sr}$ grades to $\mathrm{Sm} / \mathrm{St}$ and $\mathrm{Fl} / \mathrm{Fm}$ to $\mathrm{P}$, accompanied by an overall increase in sand over fines culminating in completely sand dominated sections. A prominent $>40 \mathrm{~m}$ channel fill characterizes the southern end of exposure, cutting into $\mathrm{Sh} / \mathrm{Sr} / \mathrm{Sfl}$ facies (Fig. 5). Here FA 3 grades upward to FA 2 facies interpreted as dune deposits, exhibiting the characteristic topography and raising to almost $60 \mathrm{~m}$ a.s.l.

\subsubsection{Interpretation}

FA 3 is interpreted as an estuary mouth sandy complex, including barrier islands/lagoon systems and tidal bars (Dalrymple et al., 1992; Dalrymple and Choi, 2007). Sp/St facies represent ebb and flood oriented migrating sand bars, ripple cross lamination in the base conforming the bottomsets of fully developed megaripple stratification. This accounts for the bidirectional paleocurrent indicators as well as fossil content. Tightly related Ssh facies represent abandoned channel fills, as inferred from crude bedding and concave up geometry. Species described within these deposits tightly resemble faunal assemblages inhabiting the bay at present time and could be related to open bay or saline conditions, although further taphonomical data are needed in order to certainly reconstruct the degree of transport to which these fossils were subjected. Sh/ $\mathrm{Sr} / \mathrm{Sfl} / \mathrm{Sht}$ along with $\mathrm{Fl} / \mathrm{C} / \mathrm{Fm}$ facies are inferred to have formed under the back barrier environment, as tidal flats and minor channel fills, including swamps and peat bogs developed as abandoned channels get filled with sediment. This is consistent with fossil wood and leaves, that together with rootlets and peat development are indicative of shallow continental environments closely emplaced amid forested areas. Sand successions exhibiting $\mathrm{Sh} / \mathrm{St}$ facies with rootlets and frequent reactivation surfaces are interpreted as washover facies. This incorporates the variability in grading and sedimentary structures as derived from the interplay between aeolian, gravitational and water driven processes, as well as vegetation incipient development since activity within this environment is virtually restricted to stormweather. The southern channelization of sand bodies $(\mathrm{Sm} / \mathrm{St})$ together with the prominent channel fill represent a tidal inlet cutting through the barrier island. The overall maturity of sand grains, as expressed by its high rounding degree is in good agreement with this interpretation since most sand within the estuary mouth complex is derived from marine reworking and barrier sands cannibalization.

\subsection{Facies association 4 (FA 4): Central estuary}

\subsubsection{Description}

This association is predominantly formed by fine sand and mud in a variety of combinations. The most abundant facies consist of horizontally stratified, subangular to subrounded sand with abundant 
mud drapes (Sht). Ripples (Sr) and flasers (Sfl) are commonly associated with this facies. Fossil bivalves (molds) and bivalve burrows are common, although density is rather low. Veneridae and Tagelus sp. have been identified (Fig. 7A), usually preserving both valves. Some fossils are still in vertical position while some others have been slightly displaced, specially where abundance increases. Small, mud filled arthropod burrows occur within $\mathrm{Sr} / \mathrm{Sfl}$ facies, attaining enough density as to obliterate primary sedimentary structures (Fig. 7B). Toward the valley edge, $\mathrm{Sr} / \mathrm{Sfl} / \mathrm{Sht}$ facies interlock with a massive or crudely bedded very fine sandstone with abundant bivalve molds (Fm; Fig. 7C). Near the center of the valley Sht grades to wavy-based trough cross bedded sandstone with abundant mud drapes (St/Sht). Sand grains are middle sized, subrounded and well sorted. Mud intraclasts accumulate within small (0.5 m wide) troughs. Calcareous fragmented material is ubiquitous. Epsilon cross bedded units occur within these central facies as isolated, $\sim 30 \mathrm{~cm}$ high and few meters wide, lateral accreting, channel shaped bodies (Fig. 7D).

\subsubsection{Occurrence}

FA 4 is widely distributed along the central portion of the estuary through the Valdivia and Tornagaleones rivers (Fig. 1) including small tributaries. It grades to FA 3 toward the coast near the western tip of Isla del Rey. Outcrops are restricted to the lower half of terraces, the upper portion remains covered by dense vegetation.

\subsubsection{Interpretation}

This facies association is inferred to have formed under the central estuarine environment (central basin in Dalrymple et al., 1992). Sht/Sfl facies forms under oscillating flow conditions, where flow velocity
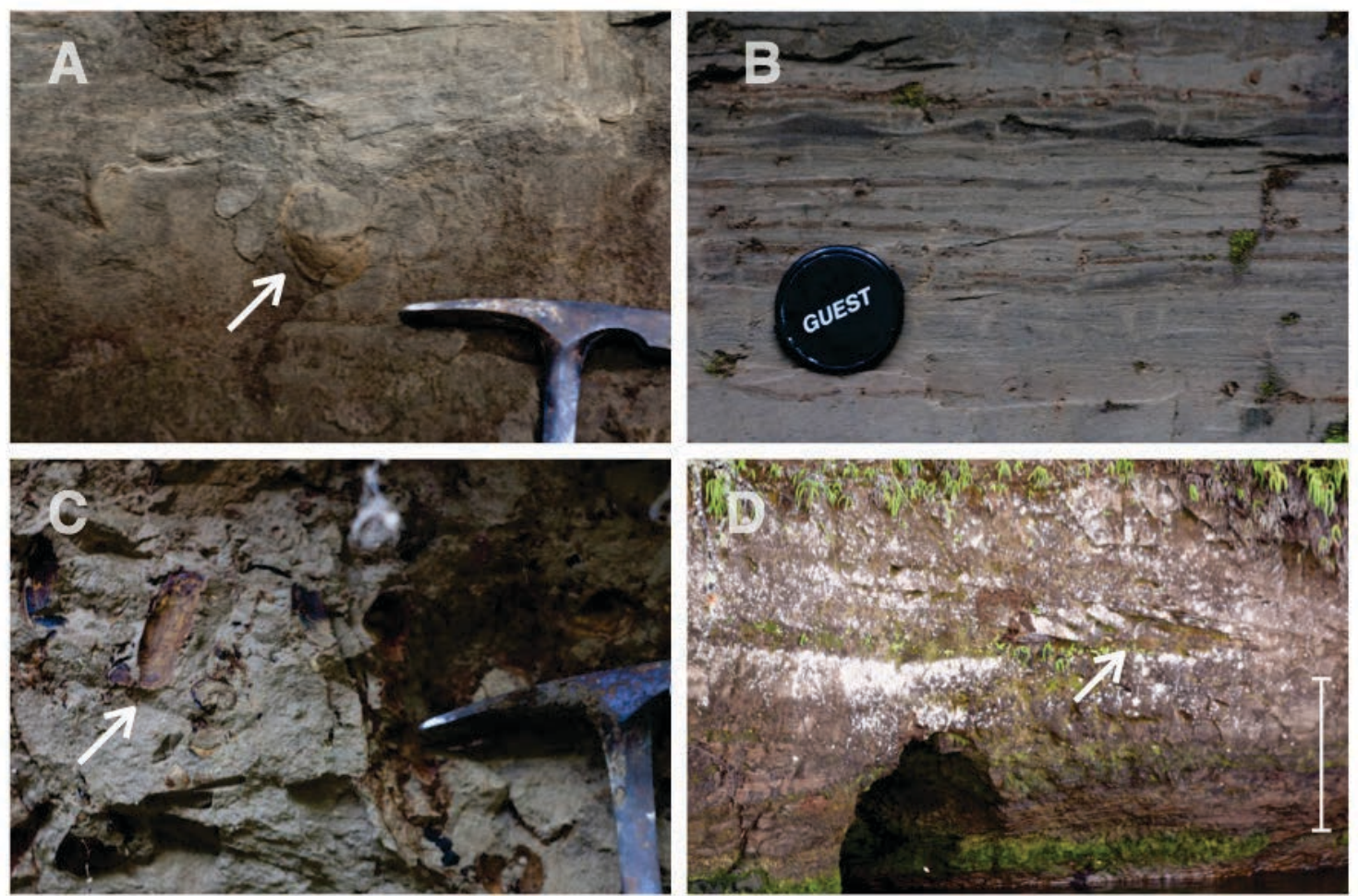

FIG. 7. Selected sedimentary facies and attributes belonging to facies association FA 4. A. Sht facies, arrow points to fossil bivalve (mold). Note abundant disrupted mud drapes; B. Sht facies with ripples and flaser bedding. Small, mud filled arthropod burrows dug into dark sand are neatly visible in the upper portion; C. Fm facies towards the valley edge in Estancilla. Arrow points to fossil Tagelus sp.; D. Lateral accreting unit (epsilon cross-bedded) within Sht/St facies, arrow indicates the lower bounding surface, accreting surfaces accumulated from left to right. Scale bar is one meter long. 
variations provide enough energy for sand transport alternating with tranquil conditions as for mud to settle. This, together with the fossil fauna might relate to slightly brackish environments. St/Sht facies toward the valley axis are thought to reflect the grading from tidal flats and marshes toward the central basin, representing tidally influenced sand bars. Both grain size increase and cross bedding agree with the transition to higher energy conditions, while mud drapes and intraclasts record the rhythmic variability between bedload and suspension depositional processes, conforming the expected channel bar facies for the central estuary (Dalrymple and Choi, 2007). Sand roundness is consistent with fluvial derived sediment.

\subsection{Facies association 5 (FA 5): Estuarine bayhead delta}

\subsubsection{Description}

This facies association gathers mud, medium to very fine sands and scarce gravel deposits. Fine sand outcrops as 1-2 $\mathrm{m}$ thick packages of mostly parallel stratified deposits (Sh). Sand grains are subangular to subrounded and moderately sorted. Rippled layers $(\mathrm{Sr})$ are disclosed as a widespread feature within Sh facies by means of mud and small plant remains accumulated as flasers, otherwise hardly noticed due to grain size homogeneity obscuring sedimentary structure (Fig. 8A). Reactivation surfaces are characterized by centimeter scale troughs or cut and fill structures filled with mud, along with slightly weathered surfaces. Isolated, concave upward, meter scale fills occur as a rather rare attribute. Poorly developed paleosoils $(\mathrm{P})$, consisting of a centimeter to decimeter thick, weathered and rootled layer are present within $\mathrm{Sh} / \mathrm{Sr} / \mathrm{St}$ facies as laterally discrete units (Fig. 8B). Laminated, deeply rootled clayey silt with occasional sand laminae or sand layers (Fl) usually cape FA 5 sequences, forming laterally extensive units (Fig. 8C). Coarser sand deposits occur as trough cross bedded units (St). Troughs are amalgamated, meter scale features filling up wider, irregularly based scours
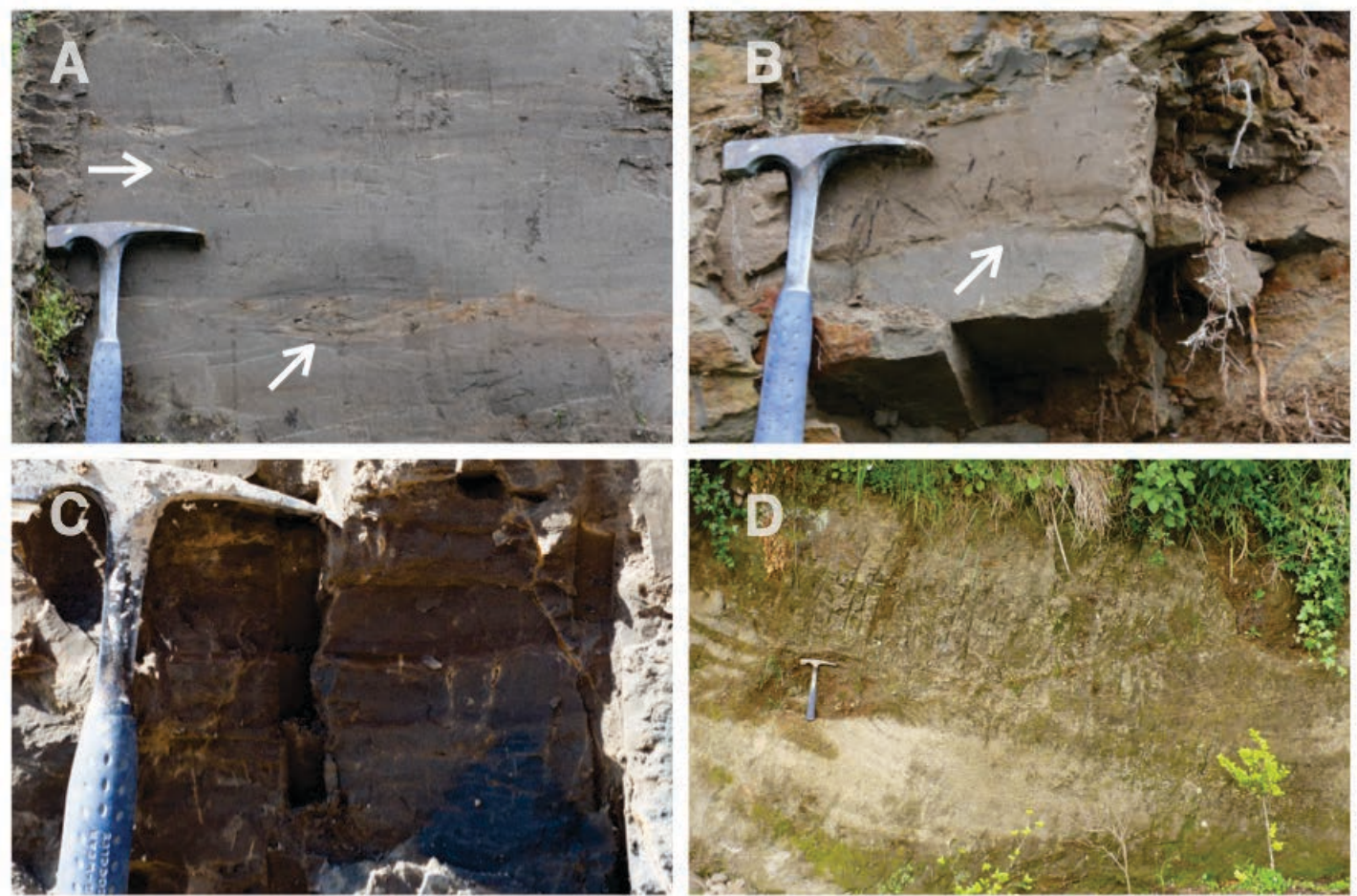

FIG. 8. Facies belonging to facies association FA 5. A. Sh/Sr facies, note mud-filled scours bounded by an erosion surface on top (lower arrow), interpreted as a reactivation surface after waning flow. Upper arrow points to small scale mud filled scours inferred to have formed as flasers; B. Weakly developed paleosoil (arrow at the base); C. Fl facies showing silica+clay coated root casts; D. St facies. 
(Fig. 8D). Sand grains are subangular to subrounded, moderately sorted and rarely include pebble-sized well rounded gravel clasts. A third, spatially related facies consists of horizontally laminated sand and mud (Sht). This facies is poorly exposed, still consistently exhibits alternating centimeter scale laminae with abundant rootlets.

\subsubsection{Occurrence}

FA 5 is distributed throughout the Valdivia city and immediate surroundings (Fig. 1B). It grades to FA 4 (central estuary) westwards and to FA 6 (fluvial) toward the north and east. It is associated with a fan shaped topography which has inherited a distributary drainage pattern, showing a down dip hight decrease remarkably conspicuous through the eastern portion of the fan.

\subsubsection{Interpretation}

Deposits conforming FA 5 are interpreted as an estuarine bayhead delta. St facies are concordant with fluvial channel deposits and are taken here to represent the riverine input to the delta, in good agreement with sand grain roundness degree and moderate sorting. Sht facies, spatially related to St and sharing grain attributes can be related to upper banks or vegetated bars. The more widespread $\mathrm{Sh} / \mathrm{Sr} / \mathrm{St}$ fine sand facies is inferred to result from a combination of unconfined and confined flow conditions, resembling the deposits of over-bank sedimentation (North and Davidson, 2012). The combination of flat beds with rippled surfaces and mud drapes is taken as the result of waning flow conditions, thus supporting the overbank interpretation. Weak paleosoil development within laterally discrete units represents subaereal exposure limited to the higher portions of sedimentary surfaces, still affected to sedimentary processes inasmuch as to hinder further pedogenic activity. Fl facies, mainly developed by suspension settling of fine particles are related here to swamps occupying the interfluve areas. The overall fan shape related to this FA, in addition to the along dip connection between fluvial and central estuary facies further supports the bayhead delta view.

\subsection{Facies association 6 (FA 6): Fluvial}

\subsubsection{Description}

This facies association is mainly composed by gravel and coarse sand deposits, but integrates sandy facies and fine sediments as well. Typical outcrops consist of trough and planar cross-stratified, well sorted gravel (Gt/Gp), bounded by concave-up or irregular surfaces. Sand or pebbly sand deposits (St/Sp) are commonly interbedded (Fig. 9A-B). Both gravel and sandy deposits are arranged in fining upward, one to two meters thick layers. Cobble sized clayey intraclasts are ubiquitous within this facies, and commonly include rootlets. There is a marked decline in gravel content following the downstream direction, giving way to mostly sand facies. Fines within this FA consist of laminated silt and mud (Fl) conforming meter scale thick deposits, alternating with St facies and extending laterally for tens of meters. Soft sediment deformation is fairly common and locally intense, giving rise to convolute bedding and associated structures (Fig. 9C-E). Within these laminae organic remains are ubiquitous, fossil leaves being most abundant. Vertical, near $30 \mathrm{~cm}$ long rootlets are fairly common.

\subsubsection{Occurrence}

FA 6 is widely distributed along the river courses, from late Pleistocene moraine ridges in the Andean piedmont toward the coast. As gravel content decreases, this facies association grades to FA 5, interpreted as an estuarine bayhead delta. The most distal gravel bearing deposits are observed in Collico and Rebellín (Fig. 1B). Downstream from this point FA 6 is rarely present, with two important exceptions. The first is an outcrop near the center of the fan, coinciding with the onset of an eastwards hight decrease trend described for FA 5. The second outcrops further toward the coast, in Isla del Rey, where it unconformably overlies FA 3 deposits. Fines are scarcely present within FA 6, usually as remnants bounded by an upper erosive surface within Gt/Gp facies. Thicker (tens of meters) and well preserved fine deposits occur around the confluence of tributaries and the Calle Calle river, between Huellelhue and Antilhue (Fig. 1B).

\subsubsection{Interpretation}

FA 6 is interpreted as fluvial deposits. Gt/Gp and $\mathrm{St} / \mathrm{Sp}$ deposits are inferred to represent channel bar facies. This is consistent with sedimentary structures and the erosive character of bounding surfaces. Along with the fining upward trend within individual layers, these deposits tightly resemble the fill of minor channels under an unstable channel 

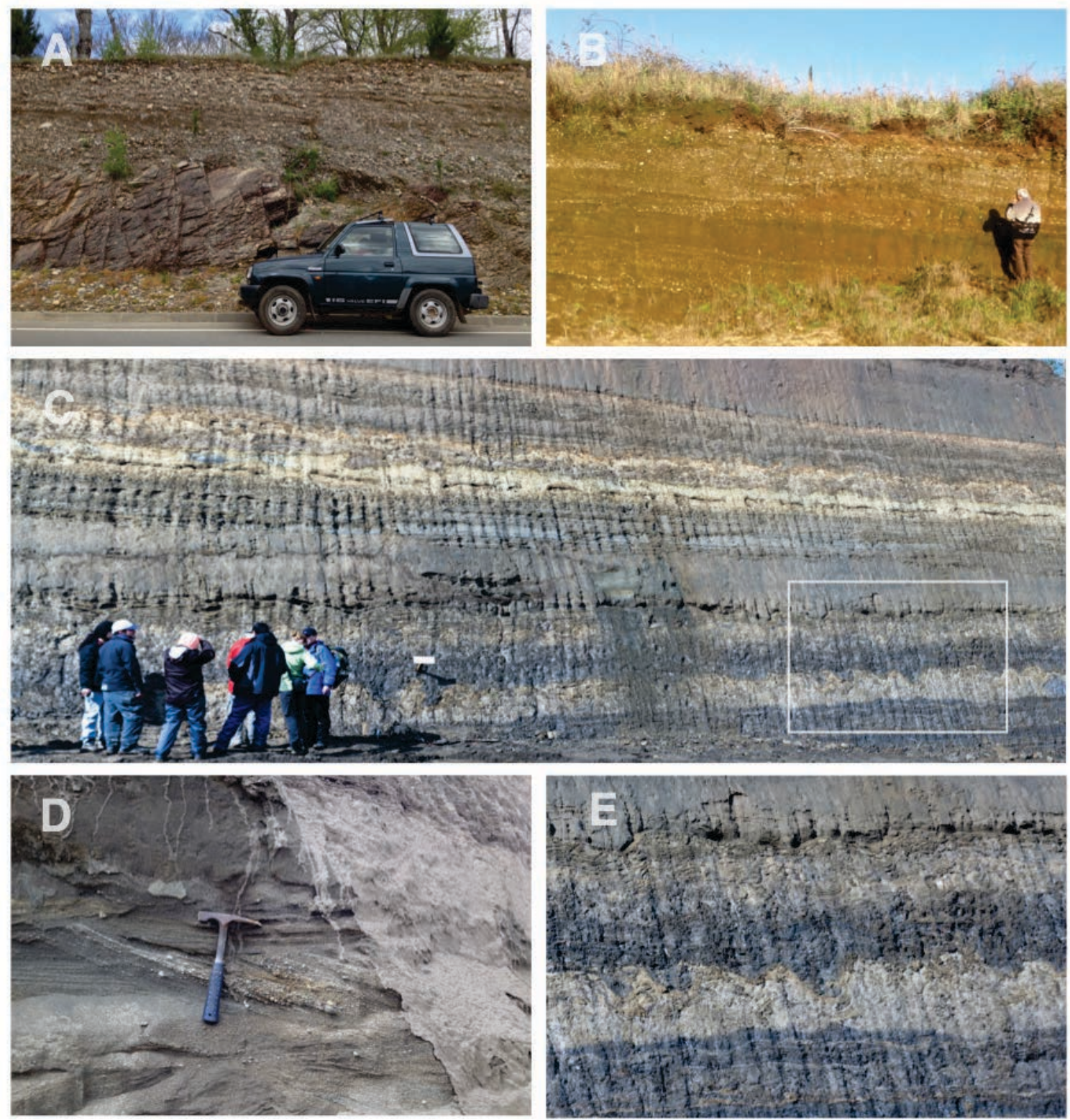

FIG. 9. Sedimentary facies and attributes belonging to facies association FA 6. A. Gp/Gt facies upstream through the Calle Calle river, near Los lagos; B. Gp/Gt and Sp/St facies downstream through the Iñaque river (Mafil); C. Fl facies alternating with St facies through the Calle Calle river, near Huellelhue, inferred as floodplain facies. White box shows area enlarged in panel E; D. Detail of St facies within section in panel C; E. Detail of Fl facies within section in panel C, note convolute bedding in contacts.

network. This is specially true around the locality of Mafil, included in a mayor fan shaped plain heading toward the Cruces river (Fig. 1). Taking into account both sedimentologic and geomorphologic character this fan is inferred to represent an abandoned braid plain. Fines are interpreted as the result of overbank sedimentation within the floodplain realm. This is in good agreement with grain size, sedimentary structures and the presence of rootlets. Soft sediment deformation would derive from high sedimentation rates during flooding events, paused by subaerial exposure periods during which vegetation developed. 


\subsection{Facies association 7 (FA 7): Slope deposits}

\subsubsection{Description}

This FA is dominated by matrix supported, poorly sorted chaotic gravel deposits (Gms). Clast size ranges from granule to cobble, with rare boulders scattered within some sections. Clasts are usually angular to subangular, but rounded clasts are not rare, specially within the coarser fraction. Four other facies commonly occur interbedded with Gms. The most common consists of moderately sorted, clast supported gravel, normally grading to coarse sand
(Gm; Fig. 10A). The base of these layers typically retains a coarse, crudely sorted gravel deposit. Medium to coarse, well sorted, parallel or horizontally stratified sand deposits $(\mathrm{Sp} / \mathrm{Sh})$ occur as lenses within this FA (Fig. 10B), sometimes related to well sorted, trough cross bedded gravel $(\mathrm{Gt})$ within the granule size range. These lenses are bounded by irregular surfaces, the upper usually erosive in character. Clay or clayey silt units are interbedded with these deposits. They commonly form laterally discrete units and show rootlet traces and abundant iron oxides (P; Fig. 10). Peat layers (C) are also encountered within this
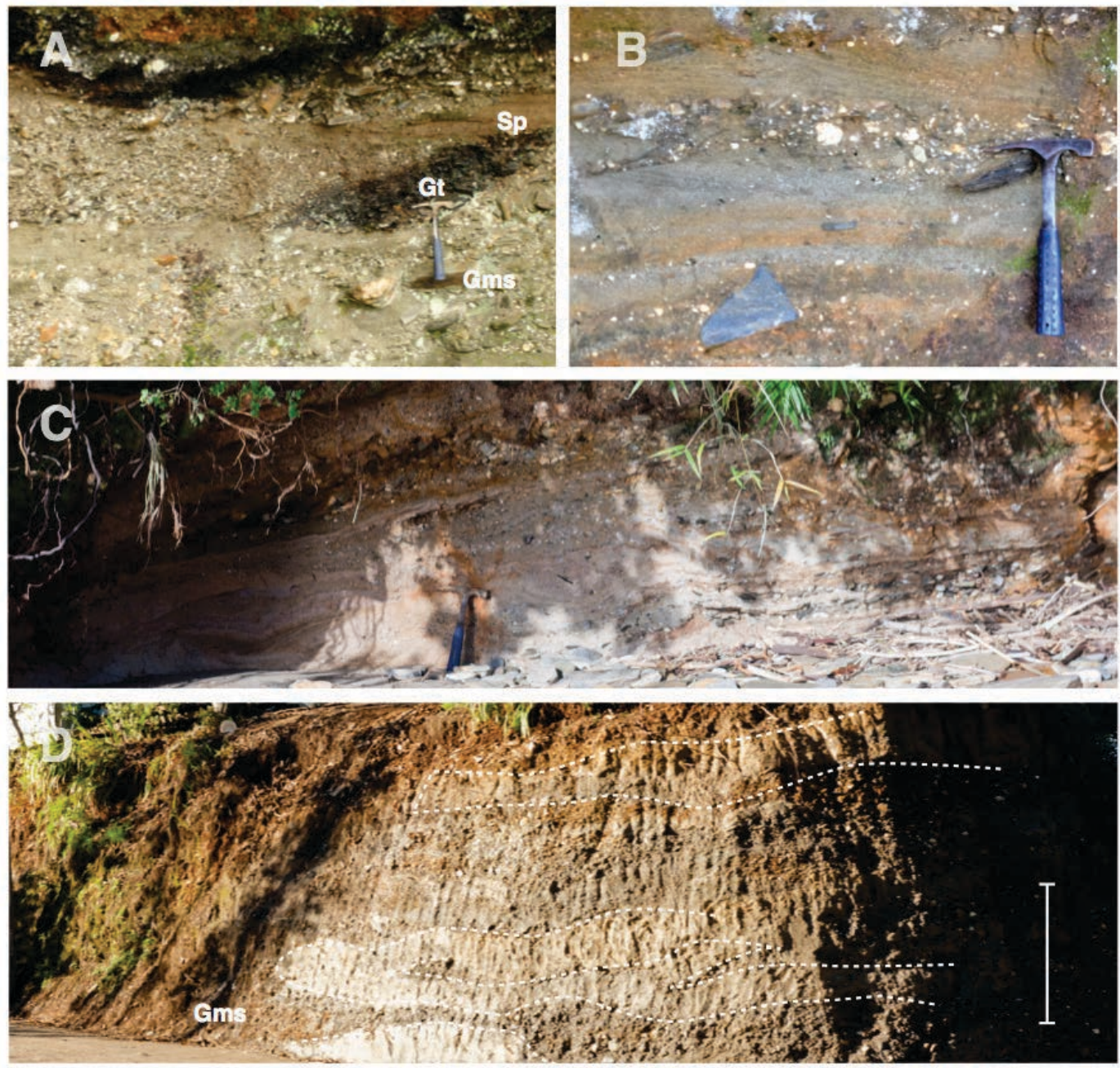

FIG. 10. Sedimentary facies belonging to facies association FA 7. A. Typical outcrop showing Gms/Gm and Sp/Sh/Gt facies; B. Detail of Sp/Sh facies; C. Interlocking with FA 3 fines in Isla de Mancera. All FA 7 deposits are confined to small catchments or hillsides, interlocking laterally with other facies associations; D. Interbedded paleosoils (P) delimited by dashed lines, distal fan facies, Agua del Obispo (1 km west from Cutipay). Scale bar is $1 \mathrm{~m}$ high. 
FA. They include abundant fossil plants including wood remains in good preservation state. Some peat layers show a high content of angular granule clasts. Clasts are predominantly derived from the local metamorphic basement. This FA includes most of what has previously been described as autochthonous facies (Latorre et al., 2007).

\subsubsection{Occurrence}

FA 7 is generally confined to the proximity to steep hillsides or small local catchments, lacking direct fluvial connection to the Andean range. Strata are often inclined, approaching horizontality as distance from the hillside increases, along with a general grain size and layer thickness decrease. They are laterally interlocked with other facies associations.

\subsubsection{Interpretation}

These deposits are interpreted as the result of alluvial, gravitational dominated sedimentary processes. Gms facies are strongly related to debris flow deposits, while Gm represents the reworking of these deposits by small streams, increasing sorting and structure but retaining a coarse lag that surpasses the stream competence. $\mathrm{Sp} / \mathrm{Sh} / \mathrm{Gt}$ facies are here related to fluvial sedimentation by minor streams, while $\mathrm{P}$ and $\mathrm{C}$ facies result from the development of soils and swamps, respectively.

\section{Discussion}

\subsection{Depositional model, paleogeography and timing}

Facies associations described so far conform neatly to the dip oriented facies distribution depicted in most estuarine facies models (Allen and Posamentier, 1993; Dalrymple et al., 1992; Dalrymple and Choi, 2007), with all major transitions from fluvial input through central estuary to the mouth complex distributed along $\sim 20 \mathrm{~km}$ (Fig. 11). Considering the prominent barrier FA and evidence of subaerial facies within FA 3 a wave dominated estuary seems likely to be the case

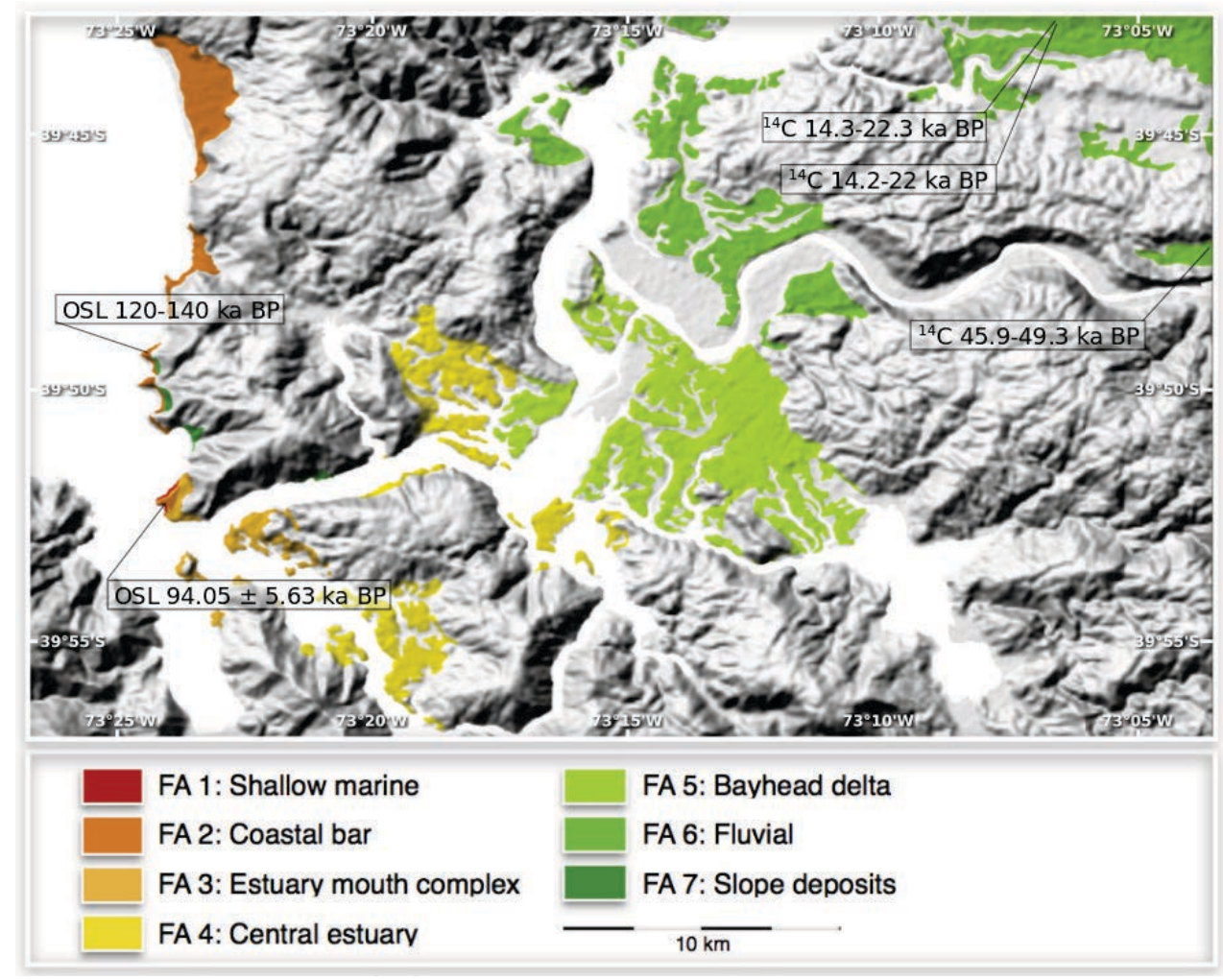

FIG. 11. Distribution pattern for facies associations described in section 4. Dating results are also included. Samples for ${ }^{14} \mathrm{C}$ dating where taken from sites not covered by this figure, see table 2 for details. 
(Dalrymple et al., 1992). This paleovalley system (sensu Blum et al., 2013) incorporates all outcrops throughout the main river courses, uncomformably overlying coastal strata distributed along the coast from the Valdivia river outlet northwards to Curiñanco (Fig. 11; Fig. 1).

A broad chronologic framework for this complex is derived from two OSL and three radiocarbon dates (Table 2). The coastal allostratigraphic unit was dated in Loncoyén through OSL on aeolian quartz grains retrieved from dune strata (FA 2), returning an age between 120-140 kaBp. The sample was taken from the basal portion of the top most Sp set, representing a maximum age for dune reactivation and migration to that point. It also gives a close estimation of a maximum age for the entire coastal bar sequence within MIS 5e. This coastal unit thus represents the last interglacial deposits, meaning that the paleovalley system involving most sediments studied here is necessarily younger. This differs from previous interpretations (Illies, 1970; Latorre et al., 2007; Rojas, 1990), although the possibility of a non strictly interglacial (MIS 5e) age has been suggested twice from paleobotanical analysis (Astorga and Pino, 2011).

The paleovalley fill directly overlies a marine ravinement surface in Playa Grande (Niebla), scarped upon shallow marine strata. This basal unit, composed of upper to lower shoreface facies (i.e., the older FA 1 unit), lies roughly at present day sea level, as opposed to MIS 5e shoreline deposits in Calfuco rising $\sim 40 \mathrm{~m}$ a.s.l. (Fig. 1B). It possibly represents early MIS 5e retrograding coastal strata, although it could certainly be older than that. Subsurface mapping and further dating is needed in order to shed light on this. Two samples within the paleovalley fill were subjected to OSL dating, one from shallow marine shoreface-foreshore deposits spatially related to the mouth bar complex and one from the central estuary FA. The latter rendered an incalculable age due to quartz OSL saturated signal. The former returned an age of $94.05 \pm 5.63 \mathrm{ka}$, relating the paleovalley fill to MIS 5c-b. This basal portion of the coastal valley fill, represents an open embayment, with barrier development restricted inasmuch as to maintain saline conditions within the bay, allowing the development of Aulacomya/Nassarius shellbeds in Isla del Rey and Ensenada San Juan. It is uncomformably overlain by a partially filled estuary complex involving barrier, central basin and fluvial/bayhead delta FAs. As opposed to the basal unit, faunal assemblages within the upper portion in Ensenada San Juan resemble the central estuary, suggesting slightly brackish rather than fully saline conditions.

Fluvial deposits extend basinward to Carboneros (Isla del Rey) through the Valdivia river while silty channelized strata (FA 5) cape the sequence through the Tornagaleones river, recording bayhead delta progradation over the filling estuary. The contact between both allostratigraphic units is easily traceable around the bay, although it varies greatly in character, from a tide ravinement surface in Playa Grande through a thick paleosoil in Playa Chica (Niebla) and

TABLE 2. OSL AND ${ }^{14}$ C DATING RESULTS.

\begin{tabular}{|c|c|c|c|c|c|c|}
\hline Sample & Location & Lab Code & $\begin{array}{l}\text { Grain size } \\
\qquad(\mu \mathrm{m})\end{array}$ & Eq dose (Gy) & $\begin{array}{l}\text { Dose rate } \\
(\mathrm{mGy} / \mathrm{yr})\end{array}$ & $\begin{array}{c}\text { OSL age } \\
\text { (kaBP) }\end{array}$ \\
\hline CAL & $39^{\circ} 49^{\prime} 12.43^{\prime \prime S} 73^{\circ} 24^{\prime} 12.43^{\prime \prime} \mathrm{W}$ & - & - & - & 0.5 & $120-140$ \\
\hline $\mathrm{PCH}$ & $39^{\circ} 52^{\prime} 24.96^{\prime \prime} \mathrm{S} 73^{\circ} 23^{\prime} 57.84^{\prime \prime} \mathrm{W}$ & UIC3526 & $250-355$ & $93.97 \pm 5.01$ & $1.00 \pm 0.016$ & $94.05 \pm 5.63$ \\
\hline EST & $39^{\circ} 5034.08^{\prime \prime} \mathrm{S} 73^{\circ} 18^{\prime} 39.6^{\prime \prime} \mathrm{W}$ & UIC3215 & $100-150$ & Saturated & - & - \\
\hline Sample & Location & Lab Code & Material & $\delta^{13} \mathbf{C}$ & $\begin{array}{l}{ }^{14} \mathrm{C} \text { age } \\
(\mathrm{kaBP})\end{array}$ & $\begin{array}{c}1 \sigma \text { age range } \\
\text { (cal kaBP) }\end{array}$ \\
\hline MAF 1 & $39^{\circ} 42^{\prime} 7.03^{\prime \prime S} 73^{\circ} 02^{\prime} 08.16^{\prime \prime} \mathrm{W}$ & AA 102300 & Charcoal & -27.1 & $15.4 \pm 3.2$ & $14.3-22.3$ \\
\hline MAF 2 & $39^{\circ} 40^{\prime} 15.51^{\prime \prime S} 72^{\circ} 58^{\prime} 43.43^{\prime \prime} \mathrm{W}$ & AA102301 & Charcoal & -27.7 & $15.3 \pm 3.1$ & $14.2-22$ \\
\hline LLAG & $39^{\circ} 51^{\prime} 3.6^{\prime \prime} \mathrm{S} 72^{\circ} 48^{\prime} 41.04^{\prime \prime} \mathrm{W}$ & UCI101677 & Wood & - & $44.3 \pm 2.1$ & $45.9-49.3$ \\
\hline
\end{tabular}


Isla del Rey, to a flat sharp surface in Ensenada San Juan (Fig. 12). The innermost trace of this contact is in Cutipay, where fluvial/tidal sand bars overlie thin fossiliferous sandstones. It is not possible to follow this surface further up dip through the central estuary FA, probably due to poor exposure as most outcrops within this portion remain half covered by vegetation.

Development of the subaerial unconformity over MIS 5c-b shoreface and tidal bar deposits requires relative sea level fall, while tidal reworking of this surface followed by barrier migration/reestablishment over Playa Grande records transgression, likely related to MIS 5b-a glacioeustatic sea level oscillation (Fig. 13).

Radiocarbon dates were obtained from fluvial sediments from Los Lagos and the Mafil-Iñaque plain, returning ages within MIS 3 and MIS 2, respectively. The connection between the latter and the bayhead delta is tight, not only in geomorphological terms but also through the smooth gradation of facies between each other, as suggested by Mella et al. (2012) (Fig. 8-9-11).

It is likely that the delta fan continued to act as a distributary system through a substantial portion of the regressive phase associated with the last glacial period, effectively linked to the sandar plains and thus to upstream controlling factors, at this time creating accommodation space through increased sediment supply (Blum and Tornqvist, 2000; Blum et al., 2013) in response to glacier fluctuations. This is related to local topographic constraints, since storage space is severely reduced by the absence of the Central Depression, upstream controlled river response signatures, such as aggradation induced by sediment overloading during glacial-deglacial periods, should be displaced downstream reaching what today are coastal regions. This scenario could account for the morphological height decrease trend of fan lobes in Valdivia toward the east, as progressively younger morphostratigraphical units that remained linked to the main fluvial systems, until incision, initiated at the coast or further into the shelf, migrated upstream eventually confining the Calle-calle and Cruces rivers to their present courses, sometime between MIS 3 and MIS 2.

This combined allo-chrono-morphostratigraphic approach allows the construction of a fourfold paleogeographic evolutionary model (Fig. 14). This model implies the development of a degradational amalgamated channel fill (Blum et al., 2013) toward the eastern portion of the bayhead delta fan, rendering a likely scenario in which this area, where up and downstream controls overlap, retains a record spanning most of the last glacial cycle, effectively portraying "mean conditions" (see Blum and Tornqvist, 2000 and Blum et al., 2013 for a discussion on this idea) rather than glacial or interglacial extremes.

\subsection{Sequence stratigraphy}

In sequence stratigraphic terms, the deposits described here correspond to a 4th-order cycle highstand prism (Catuneanu et al., 2011), punctuated by three high frecuency sequences (HFS; Catuneanu and Zecchin, 2013; Zecchin and Catuneanu, 2013), likely corresponding to sea level highstands during MIS 5e-c-a. A regressive surface of marine erosion (RSME) truncates basal shallow marine strata in Playa Grande, marking the base of the second HFS. This basal strata could belong to retrograding coastal sands related to a MIS 5e transgressive system tract (TST), although this can not be unambiguously asserted from currently available data. Back barrier facies overlying this surface represent transgressive deposits of the second HFS, and are truncated by a tidal ravinement surface (TR) and a subaereal unconformity (SU; Fig. 15). The maximum flooding surface is either cryptic or, more likely, lying below present day sea level. Other contacts used for the allostratigraphic approach are within trend facies contacts, lacking sequence stratigraphic significance. The entire coastal exposure thus corresponds to the highstand system tract (HST), and possibly a small portion of the TST in Playa Grande. If our morphostratigraphic inferences on the relation of the eastern portion of the bayhead delta fan to MIS 3-2 fluvial deposits are correct, this would belong to the falling stage system tract (FSST). Poor exposure makes the sequence stratigraphic approach rather limited for outcrop correlation here, although it will surely prove valuable for future correlation with subsurface mapping. The relationships between sequence stratigraphically and allostratigraphically derived models are depicted in figure 14 .

\subsection{Volcanic imprint}

Among all studied outcrops and having combed the area by land and water, we found no trace 

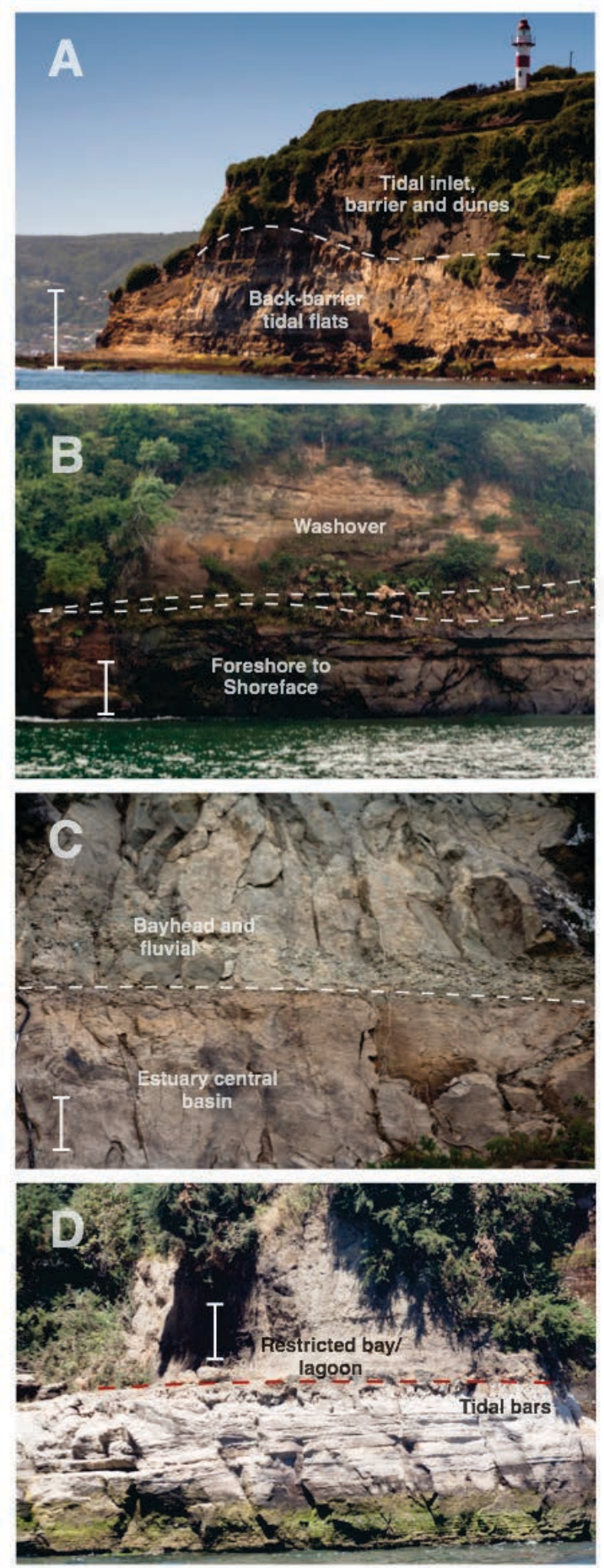

FIG. 12. Contact surfaces (dashed lines) separating both allostratigaphic units inferred to have formed during MIS 5c and MIS 5a. A. Tidal ravinement surface (TRS) in Playa Grande. Scale bar is $10 \mathrm{~m}$ long; B. Subaerial unconformity between Playa Grande and Playa Chica. This surface is a continuation of TRS in A. Scale bar is $5 \mathrm{~m}$ long; C. Sharp contact between estuarine and prograding fluvial facies, Carboneros. Scale bar is $2 \mathrm{~m}$ long; D. Flat sharp contact in Ensenada San Juan, scale bar is $2 \mathrm{~m}$ long. See text for details. 


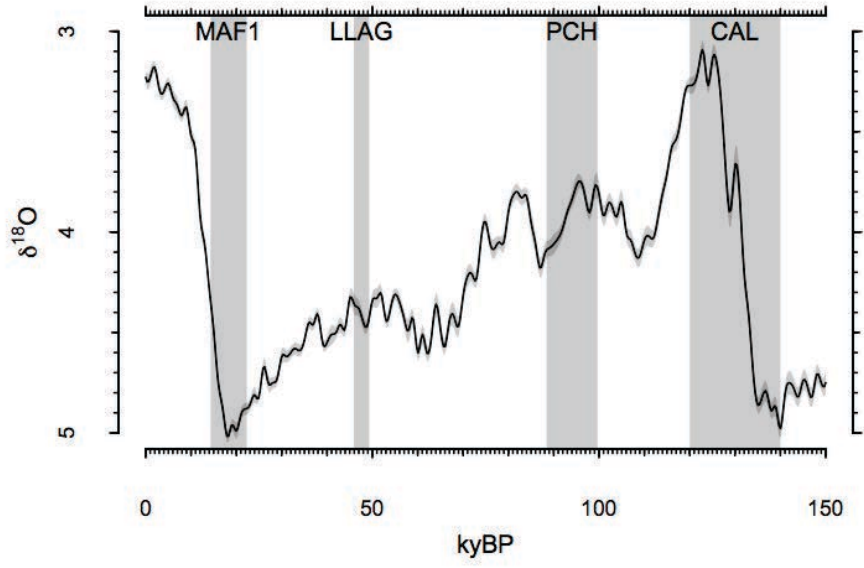

FIG. 13. ${ }^{14} \mathrm{C}$ and OSL date ranges constraining the chronostratigraphycal model for late Pleistocene infill within the area around Valdivia city, against the LR04 marine $\delta^{18} \mathrm{O} \%$ stack, reflecting global ice volume (Lisiecki and Raymo, 2005). See section 5 for discussion on context and significance of individual dates.
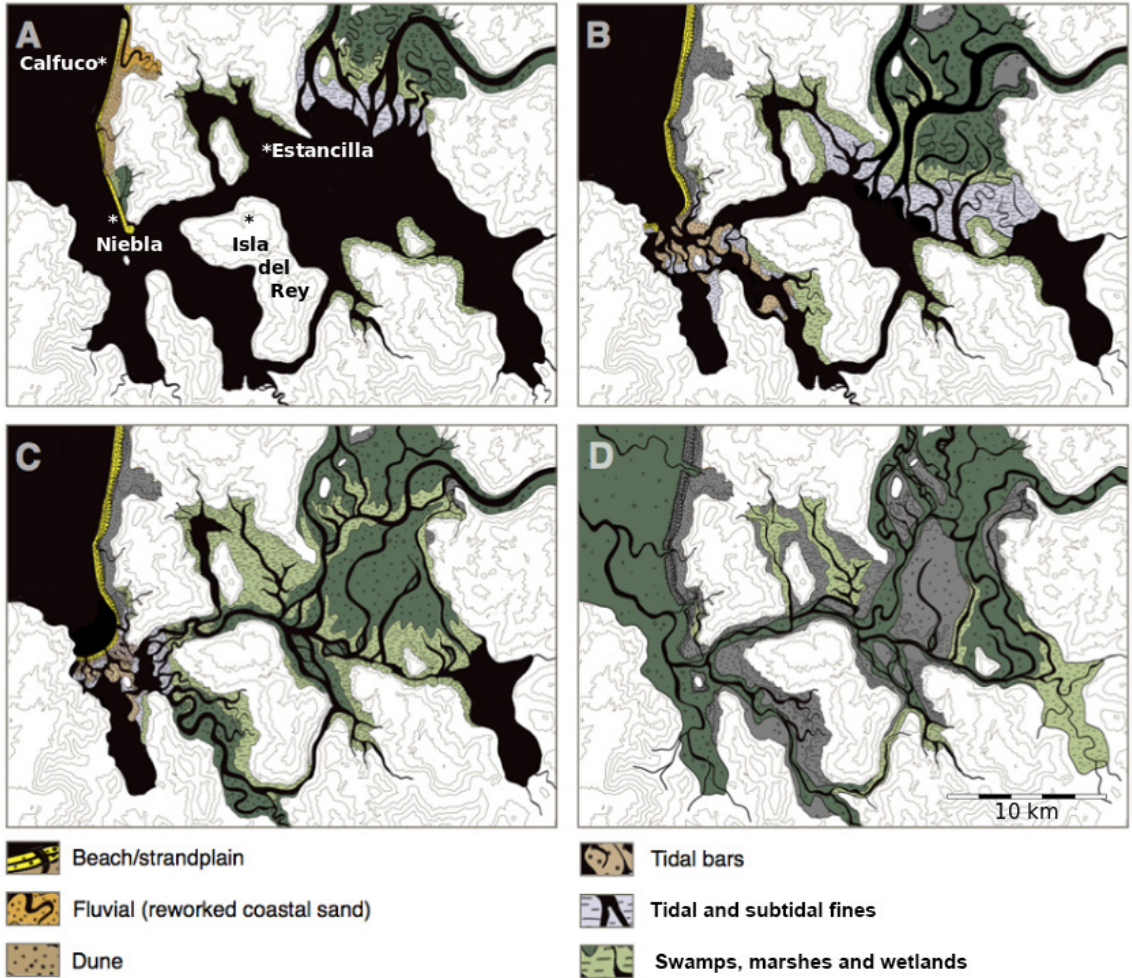

F. Tidal bars

5. Fluvial (reworked coastal sand)

N Tidal and subtidal fines

X.: Washover sand

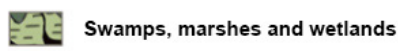

Alluvial

FIG. 14. Evolutionary model for the Valdivia basin through the last glacial cycle. A. MIS 5e. Only coastal strata remain from this stage through the NW portion of depicted area; B. MIS 5c. Wave dominated estuary with barrier development at the mouth, retaining saline conditions within the outer estuary. Central basin facies not drawn; C. MIS 5a. Partially filled estuary, bayhead delta prograded almost to the coast, restricted brackish environment within the outer estuary; D. MIS 4-2. Part of the former bayhead delta still acting as a distributary system. Accommodation space sustained by glacially induced increase in sediment supply despite sea level drop. Incision migrating upstream will eventually cause the fan to be abandoned. 


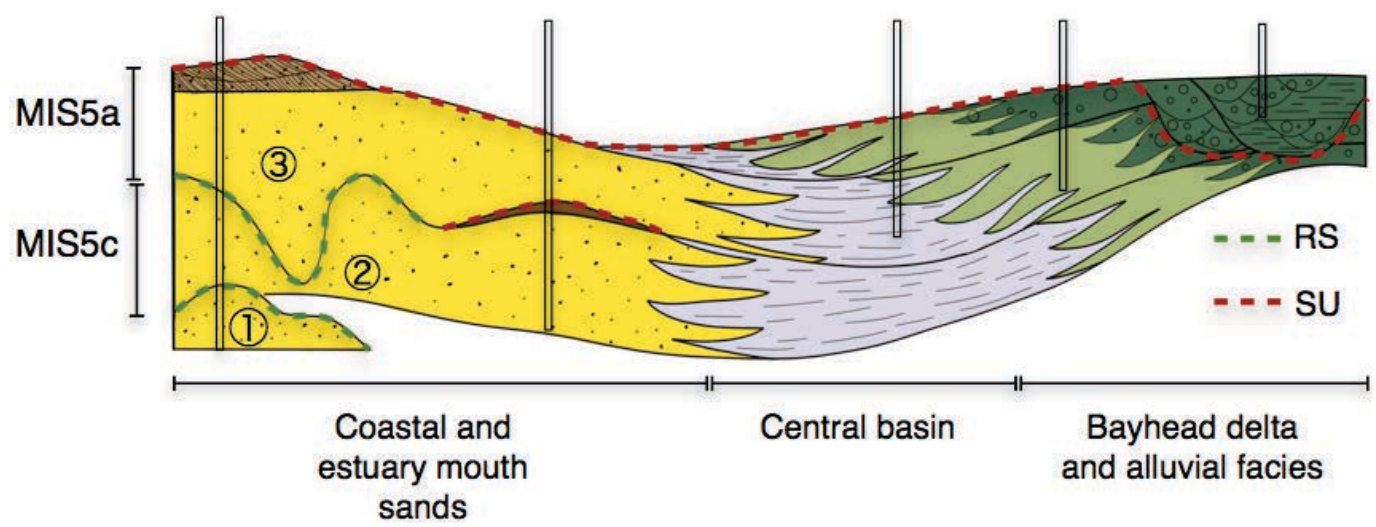

FIG. 15. Sequence stratigraphic model for the exposed late Pleistocene infill in the area around Valdivia city. Bars in the right refer to allostratigraphic units. Encircled numbers designate high frequency cycles. Vertical boxes reflect exposed sections. RS: ravinement surface, SU: subaerial unconformity.

of volcaniclastic processes direct incidence. Of course, volcanism is the main source of sediment, but paleoenvironmental reconstruction suggests this is transported and deposited in the area mainly as epiclastic material. Sediments reaching the trench off Valdivia, as described by Heberer et al. (2010), are strikingly similar to those described here. Sand grains there are commonly subangular to subrounded, as are those pertaining to river influenced FAs described above (fluvial, bayhead delta and central estuary). Furthermore, they match what is to be expected, in terms of composition, from an active forearc (Heberer et al., 2010). We therefore find no need to invoke specific volcanic events in order to account for the volcaniclastic component within these rocks. Rather than that, volcaniclastic input seems to dominate the sand sized fraction when there is a direct fluvial connection to the Andean Cordillera, while autochthonous sediments dominate in small localized catchments and slope related deposits (Mella et al., 2012). This is likely related to the lability of volcaniclastics in contrast to plutonics in the Andes. The sand sized fraction tends to accumulate within the coastal plain and nearshore environments, being tightly coupled to sea level, and thus concentrated predominantly in the highstand and lowstand coastal prisms as in the shelf. This sediment further nurtures the lower shelf and trench, accounting for the similarity between turbiditic sands and those river borne described here. Previous statements about the intensity of volcanism within interglacial periods over that of glacials based on volcaniclastic content within these rocks (Illies, 1970) are misleading, as they lack comparison with equivalent sedimentary environments through the glacial counterpart.

\section{Conclusions}

The late Pleistocene sedimentary rock sequence outcropping around Valdivia city, locally known as Cancagua, represents the last interglacial highstand prism. It is not restricted to MIS 5e but instead incorporates deposits spanning most of the last glacial cycle. MIS 5e strata outcrop exclusively within the coastal cliffs between Los Molinos and Curiñanco. Deposits exposed within the valley derive from a wave dominated estuary developed during MIS 5c-a that got almost entirely filled prior to sea level fall associated with the establishment of glacial conditions during MIS 4-2. It is likely that accommodation space remained available within the former bayhead delta after initial sea level fall in response to glacial influence on fluvial graded profile, accumulating sediments within this area as late as MIS 3-2. There is no trace of any direct impact of volcanism in the area other than being the dominant source for sedimentary systems connected to the Andean drainage.

\section{Acknowledgments}

This work was possible thanks to financial support by CONICYT, MECESUP AUS 1203 and DID-UACh 201204. R. Brümmer provided invaluable field assistance and fruitful discussions on the subject, plus friendly encouragement whenever needed. Careful revisions by Dr. W. Vivallo and Dr. P. Duhart greatly enhanced the first version, both in form and content. 


\section{References}

Allen, G.P.; Posamentier, H.W. 1993. Sequence Stratigraphy and Facies Model of an Incised Valley Fill - the Gironde Estuary, France. Journal of Sedimentary Petrology 63 (3): 378-391.

Arenas, M.; Jara, C.; Milovic, J.; Pérez, Y.; Troncoso, R.; Behlau, J.; Hanish, J.; Helms, F. 2005. Geología para el ordenamiento territorial: Área de Valdivia, Región de los Lagos. Servicio Nacional de Geología y Minería, Carta Geológica de Chile, Serie Geología Ambiental 8: 71 p., 6 mapas 1:100.000. Santiago.

Astorga, G.; Pino, M. 2011. Fossil leaves from the last interglacial in Central-Southern Chile: Inferences regarding the vegetation and paleoclimate. Geologica Acta 9 (1): 45-54.

Blum, M.; Martin, J.; Milliken, K.; Garvin, M. 2013. Paleovalley systems: Insights from Quaternary analogs and experiments. Earth-Science Reviews 116: 128-169.

Blum, M.D.; Tornqvist, T.E. 2000. Fluvial responses to climate and sea-level change: a review and look forward. Sedimentology 47: 2-48.

Carter, L.; Orpin, A.R.; Kuehl, S.A. 2010. From mountain source to ocean sink - the passage of sediment across an active margin, Waipaoa Sedimentary System, New Zealand. Marine Geology 270 (1-4): 1-10.

Catuneanu, O.; Zecchin, M. 2013. High-resolution sequence stratigraphy of clastic shelves II: Controls on sequence development. Marine and Petroleum Geology 39 (1): 26-38.

Catuneanu, O.; Galloway, W.E.; Kendall, C.G.S.C.; Miall, A.D.; Posamentier, H.W.; Strasser, A.; Tucker, M.E. 2011. Sequence Stratigraphy: Methodology and Nomenclature. Newsletters on Stratigraphy 44 (3): 173-245.

Dalrymple, R.W.; Choi, K. 2007. Morphologic and facies trends through the fluvial-marine transition in tide-dominated depositional systems: A schematic framework for environmental and sequencestratigraphic interpretation. Earth-Science Reviews 81 (3-4): 135-174.

Dalrymple, R.W.; Zaitlin, B.A.; Boyd, R. 1992. Estuarine facies models: conceptual basis and stratigraphic implications: perspective. Journal of Sedimentary Research 62 (6): 1130-1146.

De Batist, M.; Fagel, N.; Loutre, M.-F.; Chapron, E. 2008. A 17,900-year multi-proxy lacustrine record of Lago Puyehue (Chilean Lake District): introduction. Journal of Paleolimnology 39 (2): 151-161.
Denton, G.H.; Anderson, R.F.; Toggweiler, J.R.; Edwards, R.L.; Schaefer, J.M.; Putnam, A.E. 2010. The Last Glacial Termination. Science 328 (5986): 1652-1656.

Denton, G.H.; Lowell, T.V.; Heusser, C.J.; Schlüchter, C.; Andersen, B.G.; Heusser, L.E.; Moreno, P.I.; Marchant, D.R. 1999. Geomorphology, Stratigraphy, and Radiocarbon Chronology of Llanquihue Drift in the Area of the Southern Lake District, Seno Reloncaví, and Isla Grande de Chiloe, Chile. Geografiska Annaler: Series A, Physical Geography 81 (2): 167-229.

Duhart, P.; Antinao, J.L.; Clayton, J.; Elgueta, S.; Crignola, P.; McDonough, M. 2003. Geología del área Los LagosMalalhue, Región de los Lagos. Servicio Nacional de Geología y Minería, Carta Geológica de Chile, Serie Geología Básica 81: 30 p., 1 mapa 1:100.000. Santiago.

García, J.L. 2012. Late Pleistocene ice fluctuations and glacial geomorphology of the Archipiélago de Chiloé, southern Chile. Geografiska Annaler: Series A, Physical Geography 94 (4): 459-479.

García, J.L.; Kaplan, M.R.; Hall, B.L.; Schaefer, J.M.; Vega, R.M.; Schwartz, R.; Finkel, R. 2012. Glacier expansion in southern Patagonia throughout the Antarctic cold reversal. Geology 40 (9): 859-862.

Glasser, N. F.; Jansson, K. N.; Harrison, S.; Kleman, J. 2008. The glacial geomorphology and pleistocene history of south america between $38^{\circ} \mathrm{S}$ and $56^{\circ} \mathrm{S}$. Quaternary Science Reviews 27 (3-4): 365-390.

Glodny, J.; Echtler, H.; Figueroa, O.; Franz, G.; Gräfe, K.; Kemnitz, H.; Kramer, W.; Krawczyk, C.; Lohrmann, J.; Lucassen, F.; Melnick, D.; Rosenau, M.; Seifert, W. 2006. Long-Term Geological Evolution and MassFlow Balance of the South-Central Andes. In The Andes (Oncken, O.; Chong, G.; Franz, G.; Giese, P.; Götze, H.-J.; Ramos, V. A.; Strecker, M. R.; Wigger, P.; editors). Springer Berlin: 401-428. Heidelberg.

Goodbred Jr., S.L. 2003. Response of the Ganges dispersal system to climate change: a source-to-sink view since the last interstade. Sedimentary Geology 162 (1-2): 83-104.

Heberer, B.; Roser, G.; Behrmann, J.H.; Rahn, M.; Kopf, A. 2010. Holocene sediments from the Southern Chile Trench: a record of active margin magmatism, tectonics and palaeoseismicity. Journal of the Geological Society 167 (3): 539-553.

Heirman, K.; De Batist, M.; Charlet, F.; Moernaut, J.; Chapron, E.; Brümmer, R.; Pino, M.; Urrutia, R. 2011. Detailed seismic stratigraphy of Lago Puyehue: implications for the mode and timing of glacier retreat in the Chilean Lake District. Journal of Quaternary Science 26 (7): 665-674. 
Illies, H. 1970. Geología de los alrededores de Valdivia y Volcanismo y Tectónica en márgenes del Pacífico en Chile Meridional. Universidad Austral de Chile: 64 p. Valdivia.

Jain, M.; Botter-Jensen, L.; Singhvi, A.K. 2003. Dose evaluation using multiple-aliquot quartz OSL: test of methods and a new protocol for improved accuracy and precision. Radiation Measurements 37 (1): 67-80.

Kocurek, G.A. 1996. Desert aeolian systems. In Sedimentary Environments: processes, facies and stratigraphy (Reading, H.G.; editor). Blackwell Scientific Publications: 125-153.

Latorre, C.; Moreno, P. I.; Vargas, G.; Maldonado, A.; Villa-Martínez, R.; Armesto, J.; Villagrán, C.; Pino, M.; Núñez, L.; Grosjean, M. 2007. Late Quaternary environments and palaeoclimate. In The Geology of Chile (Moreno, T.; Gibbons, W.; editors). The Geological Society: 309-328. London.

Laugenie, C. 1982. La Région des Lacs, Chili Meridional. Ph.D. Thesis (Unpublished), Universite de Bordeaux: $822 \mathrm{p}$.

Lisiecki, L.E.; Raymo, M.E. 2005. A Pliocene-Pleistocene stack of 57 globally distributed benthic $\delta^{18} \mathrm{O}$ records. Paleoceanography 20: PA1003.

McCulloch, R.D.; Bentley, M.J.; Purves, R.S.; Hulton, N.; Sugden, D.E.; Clapperton, C. M. 2000. Climatic inferences from glacial and palaeoecological evidence at the last glacial termination, southern South America. Journal of Quaternary Science 15 (4): 409-417.

Mella, M.; Duhart, P.; McDonough, M.; Antinao, J.; Elgueta, S.; Crignola, P. 2012. Geología del Área Valdivia-Corral, Región de Los Ríos. Servicio Nacional de Geología y Minería, Carta Geológica de Chile, Serie Geología Básica 137: 49 p., 1 mapa 1:100.000. Santiago.

Mercer, J. 1976. Glacial history of southern south America. Quaternary Research 6: 125-166.

Miall, A.D. 1985. Architectural-Element Analysis: A New Method of Facies Analysis Applied to Fluvial Deposits. Earth-Science Reviews 22: 261-308.

Moreno, P.I.; Vilanova, I.; Villa-Martínez, R.; Garreaud, R.D.; Rojas, M.; De Pol-Holz, R. 2014. Southern Annular Mode-like changes in southwestern Patagonia at centennial timescales over the last three millennia. Nature Communications 5: 4375.

North, C.; Davidson, S. 2012. Unconfined alluvial flow processes: Recognition and interpretation of their deposits, and the significance for palaeogeographic reconstruction. Earth-Science Reviews 111: 199-223.

Porter, S.C. 1981. Pleistocene glaciation in the southern Lake District of Chile. Quaternary Research 16: 263-292.
Prescott, J.R.; Hutton, J.T. 1994. Cosmic-Ray Contributions to Dose-Rates for Luminescence and ESR DatingLarge Depths and Long-Term Time Variations. Radiation Measurements 23 (2-3): 497-500.

Quiroz, D.; Duhart, P.; Crignola, P. 2007. Geología del área Lanco-Loncoche, Regiones de La Araucanía y de Los Ríos. Servicio Nacional de Geología y Minería, Carta Geológica de Chile, Serie Geología Básica 106: 21 p., 1 mapa escala 1:100.000. Santiago.

Rehak, K.; Strecker, M.R.; Echtler, H.P. 2008. Morphotectonic segmentation of an active forearc, $37^{\circ}-41^{\circ} \mathrm{S}$, Chile. Geomorphology 94 (1-2): 98-116.

Reimer, P.J.; Bard, E.; Bayliss, A.; Beck, J.W.; Blackwell, P.G.; Ramsey, C.B.; Buck, C.E.; Edwards, L.; Friedrich, M.; Grootes, P.M.; Guilderson, T.P.; Haflidason, H.; Hajdas, I.; Hatte, C.; Heaton, T.J.; Hoffmann, D.L.; Hogg, A.G.; Hughen, K.A.; Kaiser, K.F.; Kromer, B.; Manning, S.W.; Niu, M.; Reimer, R.W.; Richards, D. A.; Scott, E.M.; Southon, J.R.; Staff, R.A.; Turney, C. S.M.; van der Plicht, J. 2013. IntCal13 and Marine13 radiocarbon age calibration curves $0-50,000$ years cal BP. Radiocarbon 55 (4): 1869-1887.

Rodríguez, C.; Pérez, Y.; Moreno, H.; Clayton, J.; Antinao, J.L.; Duhart, P.; Martin, M. 1999. Area de PanguipulliRiñihue, Región de Los Lagos. Servicio Nacional de Geología y Minería, Mapas Geológicos 10: 1 mapa 1:100.000. Santiago.

Rojas, C. 1990. La terraza fluvial de "Cancagua" en la ciudad de Valdivia: nuevos antecedentes estratigráficos y granulométricos. Revista Geográfica de Chile Terra Australis 32: 7-24.

Smith, G.A.; Lotosky, J.E. 1995. What Factors Control the Composition of Andesitic Sand? Journal of Sedimentary Research A65 (1): 91-98.

Stow, D.A. 2010. Sedimentary Rocks in the Field: A color guide. Academic Press, Elsevier inc: 320 p. London.

Strelin, J.A.; Kaplan, M.R.; Vandergoes, M.J.; Denton, G.H.; Schaefer, J.M. 2014. Holocene glacier history of the Lago Argentino basin, Southern Patagonian Icefield. Quaternary Science Reviews 101 (C): 124-145.

Wallinga, J. 2002. Optically stimulated luminescence dating of fluvial deposits: a review. Boreas 31 (4): 303-322.

Zecchin, M. 2007. The architectural variability of smallscale cycles in shelf and ramp clastic systems: The controlling factors. Earth-Science Reviews 84 (1-2): 21-55.

Zecchin, M.; Catuneanu, O. 2013. High-resolution sequence stratigraphy of clastic shelves I: Units and bounding surfaces. Marine and Petroleum Geology 39 (1): 1-25.

Manuscript received: January 16, 2017; revised/accepted: January 11, 2018; available online: January 31, 2018. 